\title{
Colonial income taxpayers and top incomes in Central Africa: Historical evidence ${ }^{1}$
}

A B Atkinson, Nuffield College, Oxford and INET at the Oxford Martin School

1. Introduction

2. Income tax data

3. Control totals for population

4. The income tax payers

5. The upper tail of the income distribution

6. Control totals for income

7. Top income percentiles and shares

8. Conclusions

\section{Introduction}

This paper presents new historical evidence about the distribution of income in the three former British colonial territories of Central Africa: Malawi, Zambia and Zimbabwe. Zimbabwe in its colonial period, under its then name of Southern Rhodesia, was a highly unequal country, but, with the notable exception of Shaul (1941), little is known about just how unequal it was. According to Kuznets (1963, Table 3), in 1946 the white settlers made up some 5 per cent of the population and received 65.3 per cent of total income. But how was this distributed among the settler population? How did the distribution change over the colonial period? What was the distributional impact of the Unilateral Declaration of Independence (UDI) and the ensuing civil war? Northern Rhodesia, now Zambia, featured in Table 3 of Kuznets (1963) as having a share of the top 5 per cent in 1946 of 45.3 per cent, but this was based solely on total non-African and African incomes, and, as Kuznets clearly recognised, understates the true inequality, telling us nothing about the inequality within these groups. Europeans in the mining industry may well have been paid considerably more than those in the government service. Equally, in the case of Malawi, previously Nyasaland, we know little about the extent of income inequality before and after the country became independent in 1964. The aim of this paper is to provide new evidence.

As in other former British colonies in Africa, the raw materials for making estimates of the historical distribution of income are very few. There

\footnotetext{
${ }^{1}$ The research for this paper has been supported by INET at the Oxford Martin School, where it forms part of the Programme for Economic Modelling (EMoD), and by the ESRC grant RES-16725-0640. I am most grateful to Facundo Alvaredo for suggesting a substantial re-structuring of the first version of this paper and to Friedrich Geiecke and Salvatore Morelli for their comments and assistance.
} 
are no household surveys covering these years. This paper makes use of a source that is both limited and imperfect - the administrative income tax tabulations - to see what can be extracted from these data in conjunction with estimates of total population and - approximate - figures for total personal income. The income tax data, which date back to 1917 in the case of Southern Rhodesia, are described in Section 2. They have been located up to the 1980s (1970 in the case of Zambia) and there do not appear to be any recent data with which they can be compared. The income tax data can only be effectively used in conjunction with control totals for the number of tax units in the country. Section 3 discusses the problems that arise in the construction of control totals for population. The numbers and characteristics of those paying income tax are described in Section 4. Who were the income taxpayers? The distributional results are presented first in terms of the shape of the upper tail. The findings in Section 5 allow us to examine the degree of concentration and how it has changed over the colonial period and years immediately after independence (including the period of UDI in the case of Zimbabwe). In order to produce results on income shares, control totals are needed for total income, and these are the subject of Section 6. As emphasised, there is considerable uncertainty surrounding the income totals, given the limited national accounts information, and this qualification has to be borne in mind when considering the results on income shares and income levels presented in Section 7. The conclusions are summarised in Section 8.

The three colonial territories were at first administered separately as the self-governing colony of Southern Rhodesia and the protectorates of Northern Rhodesia and Nyasaland. They were brought together as the Federation of Rhodesia and Nyasaland on 1 August 1953, which remained in existence until $31^{\text {st }}$ December 1963. In the course of 1964, Nyasaland became independent as Malawi, and Northern Rhodesia became independent as Zambia. Southern Rhodesia became Rhodesia, and in 1965 made a Unilateral Declaration of Independence (UDI). Independence was achieved legitimately in 1980 as the Republic of Zimbabwe. The countries are in general referred to here by their current names, with in places the addition in brackets of the then colonial name. ${ }^{2}$ The Federation - which has no current counterpart - is throughout referred to as "Rhodesia and Nyasaland".

\section{Income tax data}

The income taxes in the three countries had similar forms, and for the period of the Federation of Rhodesia and Nyasaland were under common administration. The tax was assessed in year $(t+1)$ on the total income accruing in year $t$. The latter is referred to here as Income Year $t$ (IYt). The

\footnotetext{
${ }^{2}$ The colonial names are retained in the titles of publications.
} 
introduction of the tax in each of the countries is described in each case below, together with a summary of the published statistical information.

The key data are the tabulations of taxpayers by ranges of income, showing the total numbers in each range and their total income. Since the data are grouped in this form, and the intervals do not in general coincide with the percentage groups of the population with which we are concerned (such as the top 0.1 per cent), we have to interpolate in order to arrive at the shares of total income. In the results presented here, the interpolation is based on the meansplit histogram. The rationale is as follows. Assuming, as seems reasonable in the case of top incomes, that the frequency distribution is non-increasing, then restricted upper and lower bounds can be calculated for the income shares (Gastwirth, 1972). These bounds are limiting forms of the split histogram, with one of the two densities tending to zero or infinity - see Atkinson (2005). Guaranteed to lie between these is the histogram split at the interval mean with sections of positive density on either side. ${ }^{34}$

\section{Zimbabwe}

The income tax was introduced in 1918. It was first levied on incomes accruing in the year from $1^{\text {st }}$ April 1917 to $31^{\text {st }}$ March 1918, referred to here as the income year 1917, or IY1917. The sources of the tabulated data are listed in Appendix Table A1. From the outset, information was published on the distribution of taxpayers by ranges and amounts of income. Actual income is total income after permissible deductions, such as those for interest paid, passage money and losses incurred, but excluding dividends (see below). In calculating the tax liability, there were abatements, initially $£ 1,000$ for married persons (later reduced to $\mathrm{f} 800$ with effect from the year IY1930), and $£ 500$ for other persons (reduced to $£ 360$ in IY1930), with additions of $£ 50$ per child or other dependant, and for premiums not exceeding $£ 100$ per year on policies of life assurance or annuities (Report of the Commissioner of Taxes for the year ended $31^{\text {st }}$ March, 1921, page 1). Information was supplied as to the amount of abatements, and on the basis of this information certain lower ranges were not used in the analysis. In this adjustment, a guide has been taken from the valuable contemporary work of Shaul, who stated of IY1936, when the married allowance was $£ 800$, that "owing to family allowances it is considered that the statistics of taxable incomes fail to embrace all individual

\footnotetext{
${ }^{3}$ In a few cases where the relevant percentile is close to the lower limit of the open top interval, the estimates have been obtained by extrapolation, assuming a Pareto distribution with a coefficient determined by the cumulative distribution for the top two intervals.

${ }^{4}$ The refined bounds do not apply to percentiles, since the argument involving mean-preserving transfers does not apply (see Atkinson, 2005). The percentiles have been calculated by Pareto interpolation applied to each interval using the cumulative distribution.
} 
incomes below the level of $£ 1,100$ a year" (1941, page 375). With the Income ranges available here, the data below $£ 1,501$ have been discarded for IY1918 (£2,001 in IY1917) to IY1929, and those below $£ 1,001$ for later income years. ${ }^{5}$

The income tax was levied on income excluding dividends, which were taxed in the hands of companies. In a number of years, there was in addition Supertax, where the tax base included dividends paid. (This system resembles that in South Africa - see Alvaredo and Atkinson, 2012.) Separate tabulations are available for Supertax for the years 1953 to 1968, and these are used as a check in Section 7.

\section{Malawi}

The income tax was introduced in the Income Tax Ordinance, 1921, for the financial year 1921-22 (Murray, 1932, page 290). Tax was assessed on income accruing in the previous calendar year. It should be noted that here, as in Zambia (Northern Rhodesia), the tax was levied only on non-Africans (Hailey, 1957, page 646) until 1963. The Income Tax Ordinance of 1963 integrated Africans into the income tax system (Baker, 1975, page 60).

The first published information on the distribution of taxpayers by ranges of assessable income that I have located is that made available to Phyllis Deane (1948, pages 69 and 70), covering Europeans and Asiatics separately. Strictly, the data relate to those assessed in 1938, but are taken here as relating to IY1938, since that is the year covered by Deane's income totals. Similar information for 1945 is given in Deane (1953, pages 79 and 308). From IY1953 onwards, data on incomes by ranges were published in the report produced by the Central Statistical Office of the Federation of Rhodesia and Nyasaland, Income tax statistics for the income years 1953/54-1958/59. From IY1959 up to IY1961, the series is continued in the annual Report of the Commissioner of Taxes for the Federation, but the information on the distribution is only given for the constituent countries in the case of Supertax payers (for example, Appendices VIII and IX in the Seventh Report for the year ended $30^{\text {th }}$ June 1961). The sources are listed in Appendix Table A2.

With the breakup of the Federation, the data from IY1964 covering Malawi were published in the Annual Report of the Commissioner of Taxes for the Malawi Government, the first report being that for the period 1 January 1964 to $31^{\text {st }}$ March 1968. The data continued to be published in the annual

\footnotetext{
${ }^{5}$ In general the data are published allowing for the delays in making assessments. For example, the Report of the Commissioner of Taxes for the year ended $31^{\text {st }}$ March, 1936, contained data for the IY1933 ending on $31^{\text {st }}$ March, 1934. But the only data for IY1934 ending on $31^{\text {st }}$ March, 1935 were those contained in the same report. The information from years based on only the first-assessment year is probably somewhat less complete, and these years are indicated in Appendix Table A1.
} 
reports, but also appeared in the Statistical Yearbook (SY) for various years and in Public sector financial statistics, published in 1970. The most recent data located are those for IY1980 in SY1983. The sources are summarised in Appendix Table A2.

The income tax was levied on income excluding dividends, which were taxed in the hands of companies. As in Zimbabwe, there was in certain years an additional Supertax, where the tax base included dividends paid. Separate tabulations are available for Supertax for 1953 to 1961 (for IY1959 to IY1961 these are the only data available). The system was modified in 1964 with the introduction of Pay As You Earn (PAYE), but the tabulations appear to include those on PAYE: the class A in IY1965 is defined as those with main income from employment (First Report of the Commissioner of Taxes for the period $1^{\text {st }}$ January, 1964 to $31^{\text {st }}$ March, 1968, page 19).

\section{Zambia}

The income tax was introduced with 1919-20 as the first year of assessment, referring to IY1918. The income tax data published on a regular basis in the annual reports of the Income Tax Department cover the income years 1929 to 1953, with a hiatus in the war years 1938 to 1942 inclusive. From IY1953 they were published in the report produced by the Central Statistical Office of the Federation of Rhodesia and Nyasaland, Income tax statistics for the income years 1953/54-1958/59. After the break-up of the Federation, the information was published in annual reports of the Commissioner for Taxes and later by the Ministry of Finance, although only for a small number of years ending in 1970. The sources are listed in Appendix Table A3. As for the other countries, there are Supertax data, where the income data include dividend income, covering the period 1953 to 1961.

\section{Tax administration}

The strengths and weaknesses of income tax data have been extensively discussed in the recent literature on top incomes initiated by Piketty (2001). The data are drawn from an administrative process and reflect the underlying tax legislation in their definitions of income and of the tax unit. The administrative process doubtless had many shortcomings, and tax data are affected by avoidance and evasion. Incomplete coverage of both taxpayers and income is likely to be important in the countries studied here.

The extent of tax compliance depends on the resources allocated, which were very limited. The Report of the Income Tax Department of Zambia (Northern Rhodesia) for 1933 lists (page 4) the staff as consisting of the Commissioner, the Assistant Commissioner, the Assessor, one Grade I clerk and 
two Grade II clerks. The accuracy of the information supplied by taxpayers depends on their record-keeping. The Report of the Commissioner of Taxes for the year ended 31st March, 1922 in Zimbabwe (Southern Rhodesia) notes that "considerable difficulty is experienced by the majority of farmers in preparing their income tax returns, owing to their not keeping such a full record of their transactions as is kept by merchants" (para 19). In 1947, the Report on a Fiscal Survey of Nyasaland commented that "although there has recently been a tightening up of control in the income tax as a result of the employment of additional trained staff, we are satisfied that there is still evasion and avoidance of income tax" (page 16). At the establishment of the Federation it was reported in 1954 that in Zambia (Northern Rhodesia), the "Department was grossly understaffed and the arrears of work were assuming alarming proportions. [Temporary transfer of work saved the office] from a complete breakdown, and probably preserved the sanity of the Inspector of Taxes in charge" (First Report of the Commissioner of Taxes for the three months ended $30^{\text {th }}$ June, 1954 and for the year ended $30^{\text {th }}$ June, 1955, page 3). In considering the results that follow, the reader must not lose sight of the origins of the data and the resulting limitations.

The paper is concerned with the distribution of income among residents, so that the population totals relate to the resident population, and the income total to national income rather than to domestic product. The distinction is most important in the case of the company sector, which does not form part of the analysis. For individuals, it means that we are likely to be excluding, for example, absentee landlords/estate owners, some employees on short term contracts, and some pensioners. In that sense we are not measuring the extraction of resources; rather we are asking about the economic advantage of the elite who are resident and engaged in the colonial society.

\section{Conclusion}

The income tax data must be treated with considerable caution. The measured income shares probably understate the advantages of the rich, on account of tax avoidance and evasion, and they tell us nothing about the incomes extracted by non-residents. At the same time, they provide insights into the economic circumstances of the small group at the top of the distribution paying income tax in a period about which we have virtually no other empirical information.

\section{Control totals for population}

The people recorded in the income tax statistics have to be related to the population as a whole. Since the tax data relate to tax units, which may 
comprise a couple and dependant children, the relevant total is that of the number of tax units there would be if everyone in the country were to be assessed. Such a total is considerably short of the total population, and is here derived by subtracting the estimated number of children, defined as those aged under 15, and married women (including both legal and common-law marriages). This is of course an artificial construction, but its limited purpose is to provide a scaling factor.

The total population figures for all three countries from 1950 are taken from the US Census Bureau International Database (the source used by Maddison, 2003), referred to as USCB, data available at http://www.census.gov/population/international/data/idb/informationgatewa y.php).

The pre-1950 sources and the adjustments to a tax unit basis are described for each country below.

\section{Malawi}

For the pre-1950 period, use is made of the 1945 and 1931 census figures. The 1945 population figures (Kuczynski, 1949, page 534) indicate that there was a de facto population of 2,044,707 Africans and 5,207 non-Africans ( 0.25 per cent of the total). The 1945 total of 2,049,914 may be compared with the figure of 2,816,600 for 1950 from the USCB. The implied increase in the 5 year period (37 per cent) seems unrealistic, being the same magnitude as the increase shown between 1931 and 1945 censuses. The 1950 USCB figure is also 14 per cent higher than the estimate for 1950 in the series given by the Central African Statistical Office (CASO) in the Statistical Handbook of Nyasaland 1952, Table III. Part of the difference may be due to that between de facto and de jure counts, but this can only explain some part: in 1945 the difference was some 6 per cent. Much more probable is that the earlier figures were understated. Kuczynski concluded that the 36 per cent increase between 1931 and 1945 was "most unlikely" (1949, page 637), and that the earlier figure was under-stated. In view of this, the USCB figures have been used, and, while the CASO series is taken for earlier years from 1931, it has been up-rated to coincide with the USCB series at 1950. (For 1929 and 1930, an annual growth rate of 2 per cent has been assumed.)

From the population totals, the control total for total income units is obtained by taking the proportion aged 15 and over, and then subtracting the proportion of married women. The population aged 15 and over is obtained from the UN The Size and Age Distribution of the World Populations 1994, page 530), which gives figures (referred to as the UN figures) from 1950 at 5 yearly intervals, which have here been interpolated linearly. The 1945 population figures (Kuczynski, 1949, pages 591 and 595) indicated that, out of a total population of 2,044,707 Africans, 955,289 were aged 18 and over, and that, of 
3,566 Europeans and Asiatics, 3,476 were aged 15 and over. Adding these numbers gives an adult proportion of 46.8 per cent, which is below the UN figure for 1950, as may be expected in the light of the difference between the age cut-offs. Since the UN figures indicate that the ratio was rising between 1950 and 1955, this rate of change has been extrapolated backwards.

The final total of tax units is obtained by subtracting the number of married women. In the case of the African population, a sizeable proportion of married women had husbands who were employed outside the country. The 1931 census recorded 409,521 married women but only 352,147 married men (Kuczynski, 1949, page 587). The 1945 Census recorded that among the African population there were 494,593 married women but only 367,134 married men (Statistical Handbook of Nyasaland 1952, page 17). In this case, it may be better to subtract the number of married men, since those married women with absent husbands do constitute tax units. The 1945 figures for the African population imply that subtraction of married men would reduce the total number of tax units by 18 per cent, and this proportion is applied for the total population (African and non-African) and for all years.

For Europeans, the number of tax units can be calculated from the census data. In 1945, there were 1,948 Europeans, of whom 1,614 were aged 15 and over (Kuczynski, 1949, page 599). Subtracting 493 married women gives a total of 1,121 tax units, or 0.12 per cent of the total. The figure for all nonAfricans (same source) was 0.28 per cent of total tax units.

\section{Zimbabwe}

For the pre-1950 period, use is made of the estimates of total population for census years given in the Report on the census of population of Southern Rhodesia (page 3). The figures for the non-African population ( 5 per cent of the total in 1946) are from the censuses of 1946, 1941, 1936, 1931, 1926, 1921 and 1911; the figures for the African population are estimates of the indigenous population made by the Department of Native Affairs plus estimates or census figures for aliens in employment. The figures for individual years are based on the intercensal annual growth rates as follows:

1921-26 1.68 per cent applied to years 1917 to 1925

1926-31 2.95 per cent applied to years 1926 to 1930

1931-36 3.16 per cent applied to years 1931 to 1935

1936-41 2.30 per cent applied to years 1936 to 1940

1941-46 3.94 per cent applied to years 1941 to 1950

As is noted in the Report, the fluctuations reflect migration movements rather than variations in the vital statistics.

The proportion of the population aged 15 and over is obtained from the UN The Size and Age Distribution of the World Populations 1994, page 854), 
which gives figures from 1950 at 5 yearly intervals, which have here been interpolated linearly. The problems in collecting census data on age in Zimbabwe (Southern Rhodesia) are described in the Final report of the April/May 1962 census of Africans in Southern Rhodesia: "the collection of details of individuals ages in underdeveloped countries like Southern Rhodesia with a high level of adult illiteracy is one of the most difficult census problems" (para 47). It has simply been assumed here that the proportion in years before 1950 was equal to that in 1950 .

The difficulties in securing information on marital status were even more acute. The report of the Census of population 1969 stated that "marital status data in respect of the African population was not obtained in either the 1962 or 1969 censuses due to the necessity of restricting the number of questions ... and to the difficulty of obtaining meaningful information" (page 13). For the non-African population, the 1969 census showed that married women accounted for 32 per cent of those aged 15 and over. The figures for 1956 and 1961 were 33 and 34 per cent, respectively. In the absence of information covering the whole population, it has been assumed that the number of married women to be subtracted was equal to 35 per cent of the adult population, but considerable uncertainty surrounds this extrapolation from the non-African population.

\section{Zambia}

The problems in obtaining accurate population figures for the earlier years are well described in the report of the Commission appointed to enquire into the financial and economic position of Zambia (Northern Rhodesia):

"Little reliance can be placed on the figures for the native inhabitants.

... The apparent large increase between 1911 and 1931 is probably due to a somewhat more accurate estimate, while the estimates for later years rest mainly on a basis of speculation" (quoted in Kuczynski, 1949, page 409).

Such criticism undoubtedly applies to the estimates published in the Economic and Statistical Bulletin (ESB), January 1949, Table II. These ESB figures are close to those in Mitchell, 1982, page 42 (from which the 1950 figure has been taken), but are considerably below the figures from the USCB. In view of the probable earlier under-statement, the USCB figures are used from 1950, and are linked backwards to the ESB figures for the period 1929 to 1950 by raising the latter by the ratio in 1959 (an increase of some 41 per cent). It should be noted that the number of non-Africans was initially very small but grew over this period. The breakdown of the total population in the ESB figures shows the percentage non-African as rising from 0.7 per cent in 1929 to 1.4 per cent in 1945. 
From the population totals, the control total for total income units is obtained by taking the proportion aged 15 and over, and then subtracting the proportion of married women. The proportion of the population aged 15 and over is obtained from the UN The Size and Age Distribution of the World Populations 1994, page 850), which gives figures (referred to as the UN figures) from 1950 at 5 yearly intervals, which have here been interpolated linearly. The 1931 population figures (Kuczynski, 1949, page 475) indicated that the ratio of children to adults was 70.6 to 100 . The implied proportion of adults (58.6 per cent) has been used for 1931 and the figures interpolated between 1931 and the 1950 UN figure. The 1931 proportion was also applied to 1929 and 1930. In the absence of information about marital status, it has been assumed that the subtraction of married women reduces the total population by the same factor as in Malawi (18 per cent), an adjustment that is applied for all years.

Marital status was reported for Europeans in the censuses. In 1931, there were 13,846 Europeans, of whom 2,945 were aged 15 and over (Kuczynski, 1949 , page 478). Subtracting 2,653 married women gives a total of 8,248 tax units, or 1.1 per cent of the total.

\section{Conclusion}

The control totals for tax units for the three countries are given in Table 1. In each case, they are less than half the total population: for example, in 1950 they are 36.3 per cent (Malawi), 37.1 per cent (Zambia) and 35.9 per cent (Zimbabwe) of the total population. It should be re-emphasized that the totals are based on demographic data of limited quality and on a number of strong assumptions, particularly those regarding marital status. They should therefore be interpreted with care. At the same time, they are only being used here for a limited object: they are designed to provide a sense of scale. 
Table 1 Control totals for tax units and total income

\begin{tabular}{|c|c|c|c|c|c|c|}
\hline 1917 & & & 412 & & & 15.6 \\
\hline 1918 & & & 419 & & & 12.8 \\
\hline 1919 & & & 426 & & & 13.6 \\
\hline 1920 & & & 433 & & & 13.4 \\
\hline 1921 & & & 440 & & & 13.7 \\
\hline 1922 & & & 447 & & & 14.4 \\
\hline 1923 & & & 455 & & & 14.6 \\
\hline 1924 & & & 463 & & & 12.5 \\
\hline 1925 & & & 470 & & & 12.0 \\
\hline 1926 & & & 478 & & & 14.2 \\
\hline 1927 & & & 492 & & & 16.4 \\
\hline 1928 & & & 507 & & & 16.5 \\
\hline 1929 & 637 & 736 & 522 & & 4.9 & 16.5 \\
\hline 1930 & 651 & 753 & 537 & & 5.0 & 15.5 \\
\hline 1931 & 664 & 776 & 553 & & 5.1 & 10.4 \\
\hline 1932 & 681 & 790 & 571 & & 5.7 & 11.4 \\
\hline 1933 & 693 & 786 & 589 & & 6.7 & 13.1 \\
\hline 1934 & 710 & 777 & 607 & & 8.1 & 15.7 \\
\hline 1935 & 727 & 773 & 626 & & 8.5 & 17.1 \\
\hline 1936 & 744 & 786 & 646 & & 9.0 & 19.7 \\
\hline 1937 & & 799 & 661 & & 15.8 & 22.7 \\
\hline 1938 & 778 & 807 & 676 & 7.6 & 9.8 & 24.4 \\
\hline 1939 & & 819 & 692 & & 13.7 & 25.4 \\
\hline 1940 & & 832 & 708 & & 17.4 & 26.8 \\
\hline 1941 & & 844 & 724 & & 15.9 & 28.9 \\
\hline 1942 & & 857 & 752 & & 17.3 & 29.8 \\
\hline 1943 & 871 & 863 & 782 & & 17.6 & 30.6 \\
\hline 1944 & 892 & 875 & 813 & & 15.6 & 32.5 \\
\hline 1945 & 902 & 882 & 845 & 12.2 & 14.6 & 36.4 \\
\hline 1946 & 936 & 888 & 878 & 15.6 & 15.4 & 42.2 \\
\hline 1947 & 953 & 900 & 913 & 19.0 & 17.9 & 49.3 \\
\hline 1948 & 979 & 906 & 949 & 22.3 & 22.6 & 59.8 \\
\hline 1949 & 1,000 & 927 & 986 & 23.6 & 28.7 & 68.1 \\
\hline 1950 & 1,022 & 947 & 1,025 & 24.9 & 33.6 & 84.5 \\
\hline 1951 & 1,041 & 968 & 1,060 & 28.5 & 52.5 & 92.7 \\
\hline 1952 & 1,060 & 990 & 1,107 & 35.7 & 61.6 & 111.5 \\
\hline 1953 & 1,080 & 1,013 & 1,146 & 39.1 & 78.7 & 124.2 \\
\hline 1954 & 1,102 & 1,037 & 1,188 & 55.4 & 91.1 & 133.3 \\
\hline 1955 & 1,124 & 1,062 & 1,225 & 58.7 & 117.5 & 147.4 \\
\hline 1956 & 1,147 & 1,088 & 1,260 & 63.8 & 126.2 & 167.2 \\
\hline 1957 & 1,171 & 1,114 & 1,293 & 66.9 & 109.5 & 186.8 \\
\hline 1958 & 1,197 & 1,141 & 1,327 & 71.5 & 105.3 & 200.0 \\
\hline 1959 & 1,224 & 1,169 & 1,361 & 75.0 & 135.6 & 210.7 \\
\hline 1960 & 1,252 & 1,197 & 1,396 & 79.0 & 147.1 & 216.5 \\
\hline
\end{tabular}




$\begin{array}{rrrrrrr}1961 & 1,281 & 1,225 & 1,430 & 82.3 & 144.5 & 233.0 \\ 1962 & 1,316 & 1,254 & 1,466 & 85.5 & 141.2 & 238.7 \\ 1963 & 1,351 & 1,284 & 1,500 & 88.8 & 148.9 & 246.7 \\ 1964 & 1,383 & 1,314 & 1,530 & 88.4 & 168.5 & 251.6 \\ 1965 & 1,417 & 1,347 & 1,567 & 104.2 & 235.0 & 273.0 \\ 1966 & 1,450 & 1,379 & 1,614 & 118.3 & 274.3 & 282.5 \\ 1967 & 1,489 & 1,413 & 1,664 & 124.2 & 299.0 & 303.4 \\ 1968 & 1,525 & 1,448 & 1,719 & 130.3 & 704.3 & 622.1 \\ 1969 & 1,560 & 1,485 & 1,775 & 140.9 & 875.7 & 731.2 \\ 1970 & 1,593 & 1,526 & 1,825 & 165.6 & 810.6 & 763.7 \\ 1971 & 1,631 & 1,567 & 1,882 & 421.4 & & 870.1 \\ 1972 & 1,672 & 1,610 & 1,941 & 464.6 & & 977.8 \\ 1973 & 1,715 & 1,655 & 1,988 & 462.8 & & 1,059.3 \\ 1974 & 1,769 & 1,701 & 2,046 & 600.8 & & 1,293.0 \\ 1975 & 1,848 & 1,746 & 2,102 & 684.5 & & 1,422.0 \\ 1976 & 1,920 & 1,768 & 2,163 & 753.5 & & 1,557.0 \\ 1977 & 1,977 & 1,790 & 2,222 & 893.3 & & 1,669.0 \\ 1978 & 2,036 & 1,813 & 2,274 & 1,010.2 & & 1,781.0 \\ 1979 & 2,097 & & 2,325 & 1,010.2 & & 2,128.4 \\ 1980 & 2,160 & & 2,431 & 1,237.4 & & 2,608.9 \\ 1981 & & & 2,535 & & & 3,319.1 \\ 1982 & & & 2,623 & & & 3,845.6 \\ 1983 & & & 2,740 & & & 4,656.6 \\ 1984 & & & 2,866 & & & 4,772.6\end{array}$

Note: The horizontal lines mark a change in currency. The Kwacha was introduced in Zambia in 1968 and in Malawi in 1971; the dollar was introduced in Zimbabwe in 1968. The exchange rate at the time was $£ 1=2 \mathrm{Kw}$ or $\$$. 


\section{The income tax payers}

The evidence presented here is limited to the very top of the distribution, since the income tax was only paid by a small minority. The statistics on taxpayers as a percentage of total tax units shown in Figure 1 bear out this statement. (In all cases, the statistics relate to individual taxpayers; company taxpayers are not included.) The figures are not fully comparable across time, as in some years they relate to the total number of people assessed and in other years to the total liable for tax, but they are sufficient to demonstrate that only a small minority of the population are covered by the income tabulations. At the outset, in the pre-war period, taxpayers numbered less than 0.5 per cent of the total tax units. This means that the distributional information relates only to the very top of the distribution: the top 0.25 per cent or smaller groups, such as the top 0.1 per cent or the top 0.01 per cent. After the Second World War, the numbers rose, reaching 1 per cent in Malawi (MA) and Zambia (ZA). In Zimbabwe (ZI) they approached 5 per cent.

In Malawi and Zambia, the colonial tax was only levied on non-Africans, and the expansion of the number of taxpayers in the former case after independence in 1964 may be seen to be related to the increasing number of Malawian taxpayers. The income tax data for Malawi disaggregated by race are shown for the years 1964 to 1972 in Figure 2. The number of Malawian taxpayers rose by a factor of more than eight, passing first the Asian taxpayers and then the "Other" group, which included Europeans. In Malawi, Asians had long constituted an important proportion of income taxpayers, as may be seen from the figures in Table 2 for the years 1929 to 1935. "Indians" are shown as a separate category, accounting for around half of all individual taxpayers.

In Zimbabwe (then Rhodesia) the number of African taxpayers also rose over this period - see the dashed line in Figure 2 - but less rapidly, and in the early 1970s the number was under half that in Malawi.

Taxpayers by occupation and industry - pre-Federation

Where were the taxpayers engaged under the colonial regime? In taxing salaries, public employees were a natural target group. The sources of the gross income of individual taxpayers in Zambia (Northern Rhodesia) over the period 1925 to the formation of the Federation (the last year shown is 1952) are shown in Figure 3, from which it may be seen that public employment salaries accounted for a fairly steady 10-20 per cent. But private employment was larger, starting at 35 per cent and rising rapidly in the decade after 1925 with the expansion of the mining industry. Income from farming, and from trade and professions, declined as a proportion and indeed fell absolutely in 
the depression of the early 1930s. From the mid-1930s to the 1950s there was little further change in the proportionate contributions. Overall, wages and salaries accounted for around three-quarters of the gross income of taxpayers in Zambia at this time, with self-employment and property income accounting for the remaining quarter.

In Malawi, non-Indian income taxpayers were classified by category in the 1920s and 1930s - see Table 2 . The remaining taxpayers were accounted for by planters, company employees, civil servants, and missionaries. In contrast to Zambia, company employees were similar in number to civil servants and there was little relative growth. It is noteworthy too that there were almost as many missionaries as civil servants.

The sources of income for taxpayers in Zimbabwe (Southern Rhodesia) are shown for the period 1917 to 1947 in Figure 4. Public employment grew over the period, but accounted for only a modest amount, reaching 10 per cent of total gross income by 1947. In contrast, private employment employees constituted a larger fraction and one that more than doubled, reaching 36 per cent by 1947. Taken together, the share of employment rose from around 20 per cent to nearly half. The varying fortunes of different parts of the economy can be traced in the shares of mining, farming and trade. Income from the professions and investment income, shown on the right hand axis, accounted for between 10 and 20 per cent of the income assessed for individuals in the pre-war period, but were lower after the war.

Taxpayers by occupation and industry - during the Federation

How had the position changed by the mid-1950s? The composition by employment and by share of taxable income is shown in Table 3, where taxpayers for all three constituent countries are classified according to their main source of income in IY1957.

Setting the countries side by side brings out differences. In Zambia, the great majority of taxpayers have their main income from employment: 91 per cent of taxpayers and 86 per cent of taxable income. In Malawi and Zimbabwe, the proportions are more like 80 per cent and 70 per cent. In both these countries, there are larger contributions from profit income and investment income, the former being more important in Malawi and the latter in Zimbabwe. Government employment is similar in the Rhodesias, but larger in Malawi. As may be expected, mining employment is higher in Zambia, and agricultural profit income is higher in Zimbabwe. By comparing the taxpayer percentages and income shares, it may be seen that employment incomes tended to be smaller and profit incomes higher. Government employees tended to receive less. 
Taxpayers by occupation and industry - after independence/UDI

For Malawi and Zimbabwe there is evidence for the post-Federation period. In the case of Malawi, Table 4 shows the percentage composition of taxpayers (corresponding to the first of the columns for this country in Table 3) from 1964 (year of independence) to 1979. There are quite major changes, although some of these may reflect changes in classification (for example, the fall in retail trade and the rise of services). Government employment fell until 1976 and then rose. Agricultural employment fell. There was a rise in the proportion of taxpayers receiving investment income, even if the total remained modest.

A less detailed breakdown for Zimbabwe is shown in Figure 5, covering the years 1963 to 1984. As far as the three main categories - employment, self-employment, and investment/pensions - are concerned, there was remarkable stability in the proportions of taxpayers, despite the major events that occurred in this period (UDI in 1965, UN sanctions, civil war, majority rule). The proportion with employment as the main source, already high, rose slightly; the proportion with self-employment fell. The proportion with investment income and pensions was broadly stable at around 5 per cent.

\section{Conclusions}

The income taxpayers in Central Africa last century were quite a varied group. They were not all European settlers; they were not all employees of government or mining companies. In Malawi and Zambia, the colonial tax was only levied on non-Africans, but a substantial proportion of income taxpayers in the former country were Indians: around 50 per cent of taxpayers in the 1930s. In Zimbabwe, there were African taxpayers before independence.

In terms of economic activity, while employees of government and of private companies accounted for the majority of taxable income in Zambia before the Federation, a quarter was income from self-employment, farming or the ownership of property. In Zimbabwe, these categories accounted for at least a quarter of income subject to tax. Comparing the countries in the Federation period, we see noticeable differences. As may be expected, mining employment is higher in Zambia, and agricultural profit income is higher in Zimbabwe. A substantial contribution is made by profit income (Malawi) and investment income (Zimbabwe).

Over time, there were major changes, such as the growth of the copper industry in Zambia, the much greater importance of employment income in Zimbabwe during the period it was Southern Rhodesia, and the rise in the 
number of Malawian taxpayers after independence. It is interesting to ask whether these developments can be detected in the distribution of income, to which I now turn. 
Table 2 Individual taxpayers by group in Malawi (Nyasaland) 1929 to 1935

$\begin{array}{lrrrrrrr}\text { Income year } & 1929 & 1930 & 1931 & 1932 & 1933 & 1934 & 1935 \\ & & & & & & & \\ \text { Planters and } & 12.8 & 12.9 & 11.6 & 11.2 & 10.3 & 10.5 & 9.5 \\ \text { planters' assistants } & & & & & & & \\ \text { Partnerships, traders } & 1.7 & 2.0 & 2.1 & 2.3 & 2.5 & 2.5 & 2.5 \\ \text { Company employees } & 12.4 & 11.8 & 11.0 & 11.7 & 12.2 & 12.1 & 12.2 \\ \text { Civil servants } & 10.3 & 11.5 & 11.4 & 11.4 & 13.0 & 13.4 & 13.4 \\ \text { Missionaries } & 9.9 & 8.4 & 10.3 & 8.6 & 9.5 & 8.4 & 9.0 \\ \text { Indians } & 50.9 & 51.1 & 50.7 & 52.4 & 49.9 & 50.7 & 50.9\end{array}$

Sources: Financial Reports, 1932 to 1936, Appendix XII 
Table 3 Source of main income 1957/8

Zambia (Northern

Rhodesia)

Source
Taxpayers per cent
Taxable income per cent
Malawi (Nyasaland)

Taxpayers per cent
Zimbabwe (Southern Rhodesia)

Taxable income Taxpayers per cent
Taxable income per cent

Main income from employment

Agriculture
Mining
Manufacturing
Building and construction
Transport
Wholesale and retail trade
Finance and insurance
Services
Government

TOTAL from employment

$\begin{array}{rr}0.6 & 0.4 \\ 32.1 & 33.9 \\ 3.7 & 3.8 \\ 8.4 & 8.2 \\ 6.4 & 5.1 \\ 11.1 & 10.6 \\ 3.0 & 2.1 \\ 5.9 & 5.1 \\ 19.8 & 16.9\end{array}$

91.0

86.0

$\begin{array}{rr}9.7 & 10.3 \\ 0.4 & 0.2 \\ 4.4 & 4.0 \\ 6.3 & 5.2 \\ 6.3 & 5.2 \\ 7.5 & 7.2 \\ 2.7 & 1.9 \\ 8.4 & 6.8 \\ 32.5 & 27.6\end{array}$

Main income from other sources

Agriculture

1.6

Mining

Manufacturing

$0.4 \quad 0.8$

Building and construction

0.7

1.1

1.0

1.6

10.6

15.0

1.2

1.6

Wholesale and retail trade

2.4

3.5

2.3

3.6

2.6

5.1

Services

$1.5 \quad 3.0$

15.9

23.6

10.2

18.7

Rents

0.5

0.8

1.1

1.3

1.3

1.6

Interest and dividends

0.6

1.3

2.0

4.0

3.5

5.5

Pensions

$1.1 \quad 2.1$

3.5

5.6

5.9

7.8

Sources: Federation Income Tax Statistics, 1953/54-1958/59, volume III, Northern Rhodesia, Table 1, volume IV, Nyasaland, Table 1; Rhodesia, Income Tax Statistics, 1953/54-1962/63, Table 3.

Note: categories omitted are "Other" and Miscellaneous", and where less than 0.4 per cent of taxpayers. 
Table 4 Income taxpayers in Malawi 1964 to 1979

\begin{tabular}{|c|c|c|c|c|c|c|c|c|c|c|c|c|c|c|}
\hline 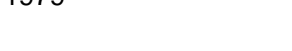 & 1964 & 1965 & 1966 & 1967 & 1970 & 1971 & 1972 & 1973 & 1974 & 1975 & 1976 & 1977 & 1978 & 1979 \\
\hline Agriculture employees & 6.3 & 5.6 & 5.2 & 4.6 & 3.2 & 3.1 & 2.8 & 2.9 & 2.8 & 2.7 & 2.5 & 2.5 & 2.0 & 1.8 \\
\hline $\begin{array}{l}\text { Mining and } \\
\text { manufacturing } \\
\text { employees }\end{array}$ & 2.5 & 2.9 & 3.8 & 6.0 & 4.0 & 3.8 & 3.5 & 3.0 & 3.3 & 3.1 & 3.2 & 3.1 & 2.7 & 3.3 \\
\hline $\begin{array}{l}\text { Building and } \\
\text { construction } \\
\text { employees }\end{array}$ & 1.3 & 2.8 & 3.0 & 2.1 & 3.1 & 2.3 & 1.7 & 1.3 & 1.4 & 1.5 & 1.4 & 1.5 & 1.8 & 1.9 \\
\hline Transport employees & 6.0 & 5.7 & 5.8 & 6.1 & 4.6 & 4.8 & 5.0 & 4.9 & 5.3 & 5.5 & 5.3 & 4.8 & 5.0 & 5.4 \\
\hline $\begin{array}{l}\text { Wholesale and retail } \\
\text { trade employees }\end{array}$ & 7.1 & 6.8 & 6.3 & 7.0 & 4.2 & 3.3 & 2.6 & 2.0 & 2.0 & 1.7 & 1.2 & 0.9 & 0.7 & 0.6 \\
\hline $\begin{array}{l}\text { Wholesale/retail trade } \\
\text { and services self } \\
\text { employed }\end{array}$ & 20.3 & 18.8 & 16.3 & 17.2 & 11.8 & 11.1 & 10.8 & 9.6 & 9.8 & 9.7 & 7.3 & 6.8 & 5.9 & 7.2 \\
\hline $\begin{array}{l}\text { Finance and } \\
\text { insurance employees }\end{array}$ & 2.8 & 2.5 & 2.7 & 3.1 & 2.7 & 3.0 & 3.4 & 3.3 & 3.6 & 3.5 & 3.6 & 3.6 & 3.0 & 3.2 \\
\hline Services employees & 13.0 & 16.1 & 14.9 & 14.9 & 20.2 & 22.7 & 28.3 & 29.2 & 28.5 & 29.0 & 33.2 & 33.8 & 35.7 & 32.4 \\
\hline $\begin{array}{l}\text { Services self- } \\
\text { employed }\end{array}$ & 2.6 & 2.5 & 2.4 & 2.7 & 1.9 & 2.1 & 2.2 & 2.0 & 2.1 & 2.2 & 2.1 & 2.1 & 2.1 & 2.1 \\
\hline $\begin{array}{l}\text { Government } \\
\text { employment }\end{array}$ & 31.4 & 29.7 & 28.9 & 25.2 & 24.8 & 24.3 & 23.4 & 25.3 & 23.8 & 23.4 & 23.4 & 23.7 & 26.6 & 28.1 \\
\hline $\begin{array}{l}\text { Rents, dividends, } \\
\text { interest and pensions }\end{array}$ & 3.2 & 4.4 & 8.5 & 7.7 & 16.1 & 15.6 & 12.4 & 12.3 & 12.6 & 12.3 & 11.0 & 10.5 & 8.8 & 8.1 \\
\hline Total & 100 & 100 & 100 & 100 & 100 & 100 & 100 & 100 & 100 & 100 & 100 & 100 & 100 & 100 \\
\hline
\end{tabular}

Sources: Public Sector Financial Statistics 1970, Table C2;

Malawi Statistical Yearbook 1982, Tables 15.7 and

15.8

Note: cases only shown where more than 50 taxpayers; miscellaneous and agricultural self-employed also excluded. 
Figure 1 Taxpayers as per cent of total tax units

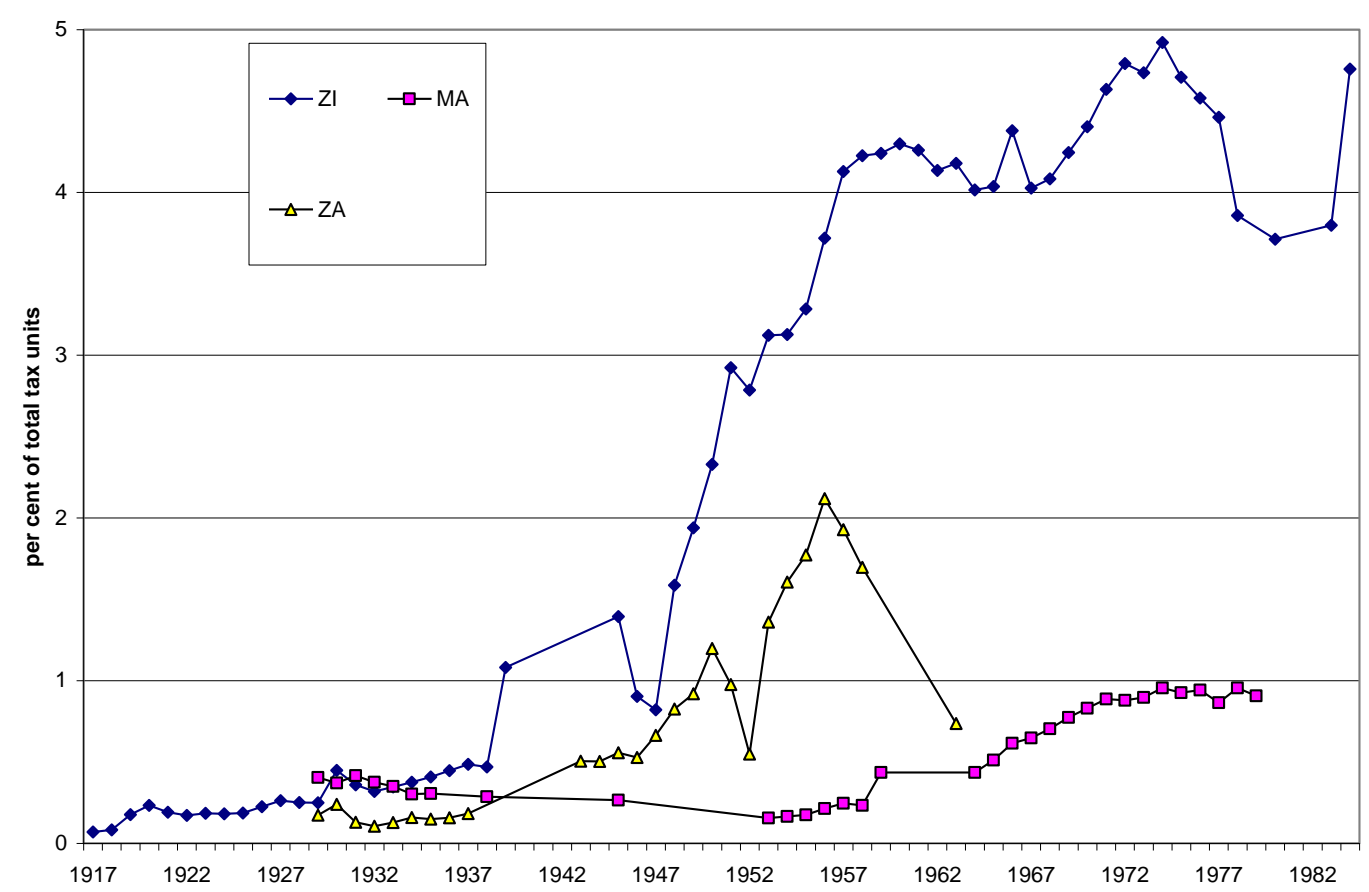

Source: see Tables A1 to A3.

Figure 2 Number of income taxpayers by race in Malawi, and African taxpayers in Zimbabwe

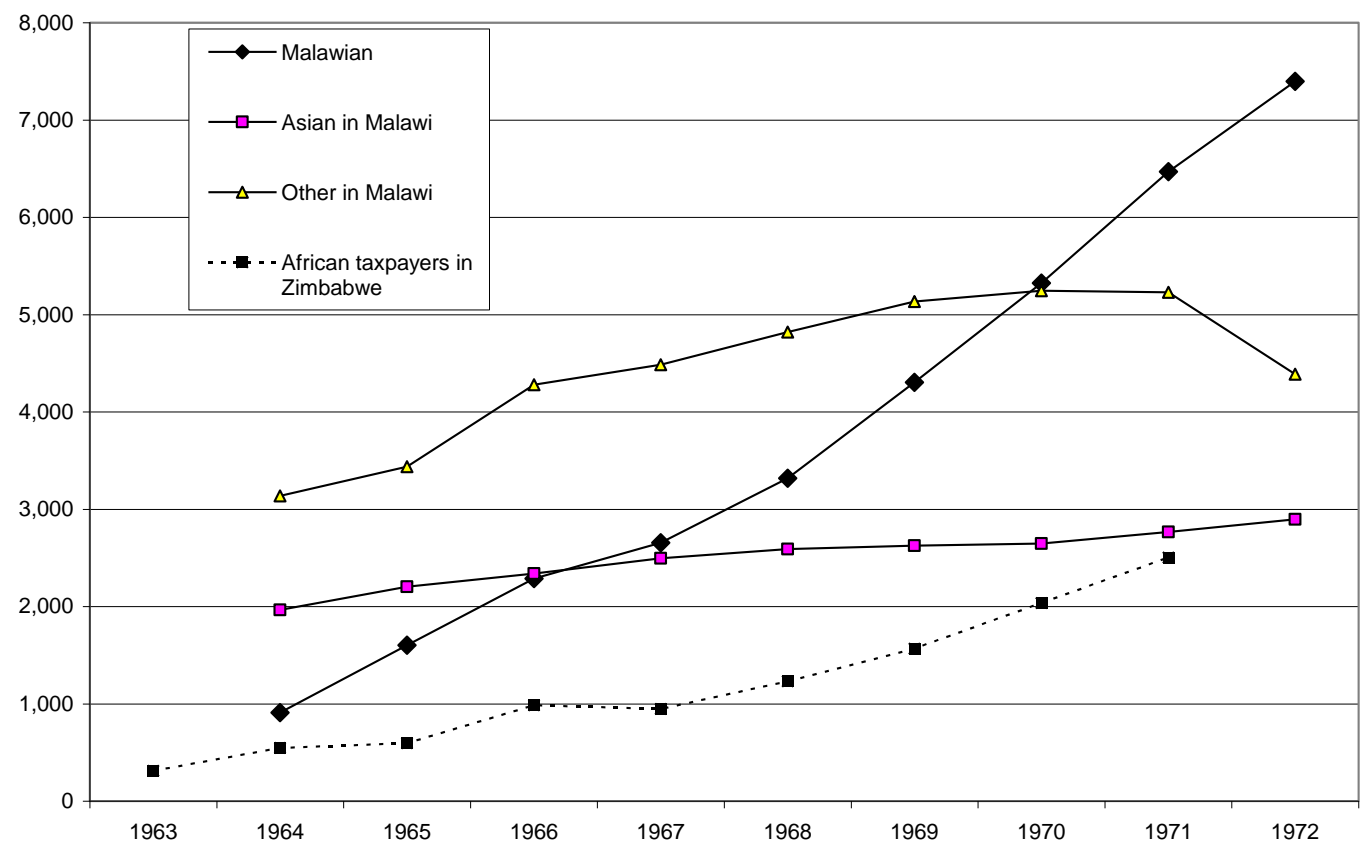

Source: Malawi Statistical Yearbook 1975, Table 16.14, and AR Rhodesia year ended June 1966, para 9, June 1969, para 9, June 1972, para 5 and June 1973, para 4. 
Figure 3 Sources of gross income Zambia (Northern Rhodesia) 1925 to 1952

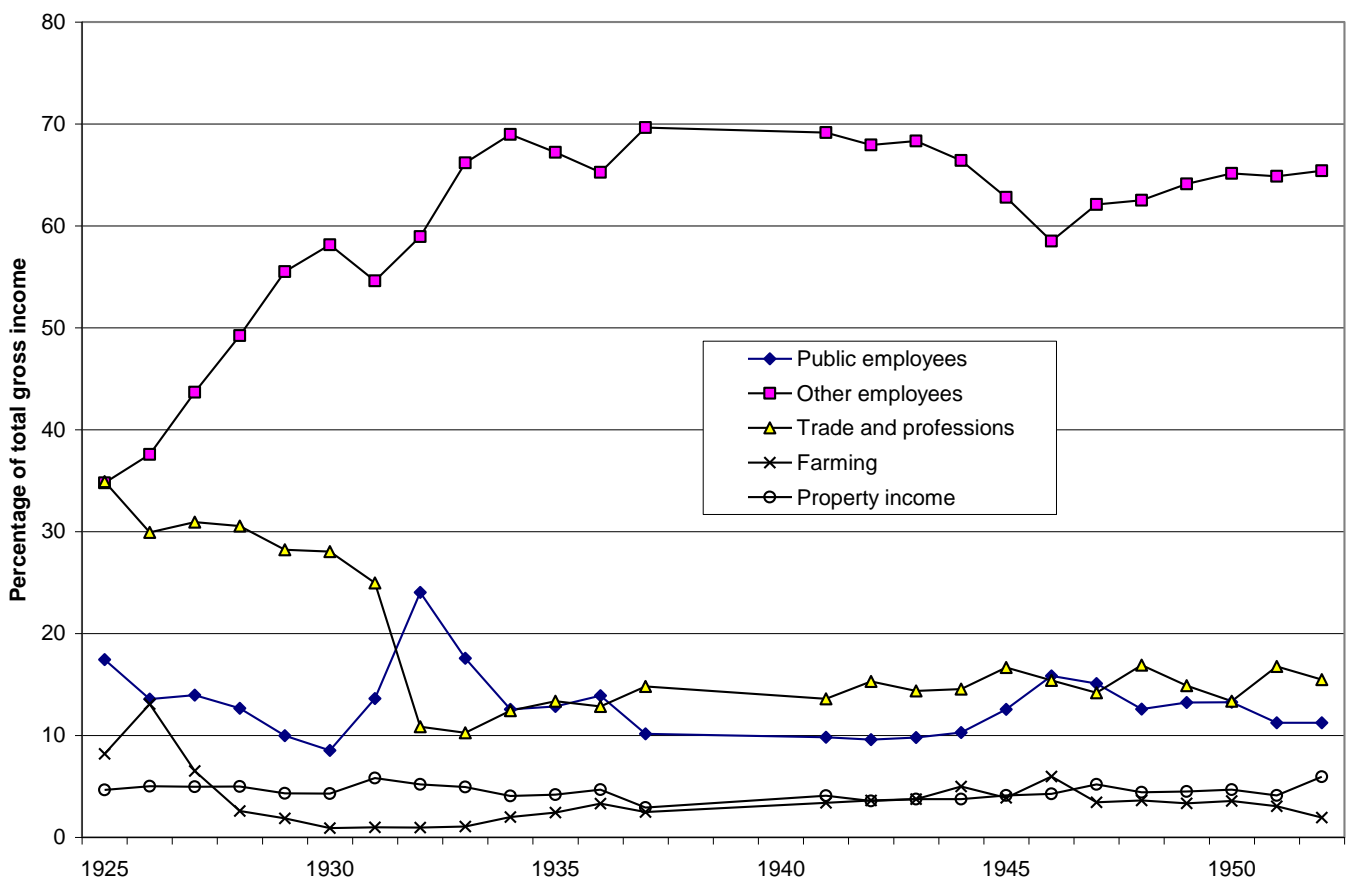

Source: See Table A3, Schedule A.

Figure 4 Sources of income (after losses) in Zimbabwe (Southern Rhodesia) 1917 to 1947

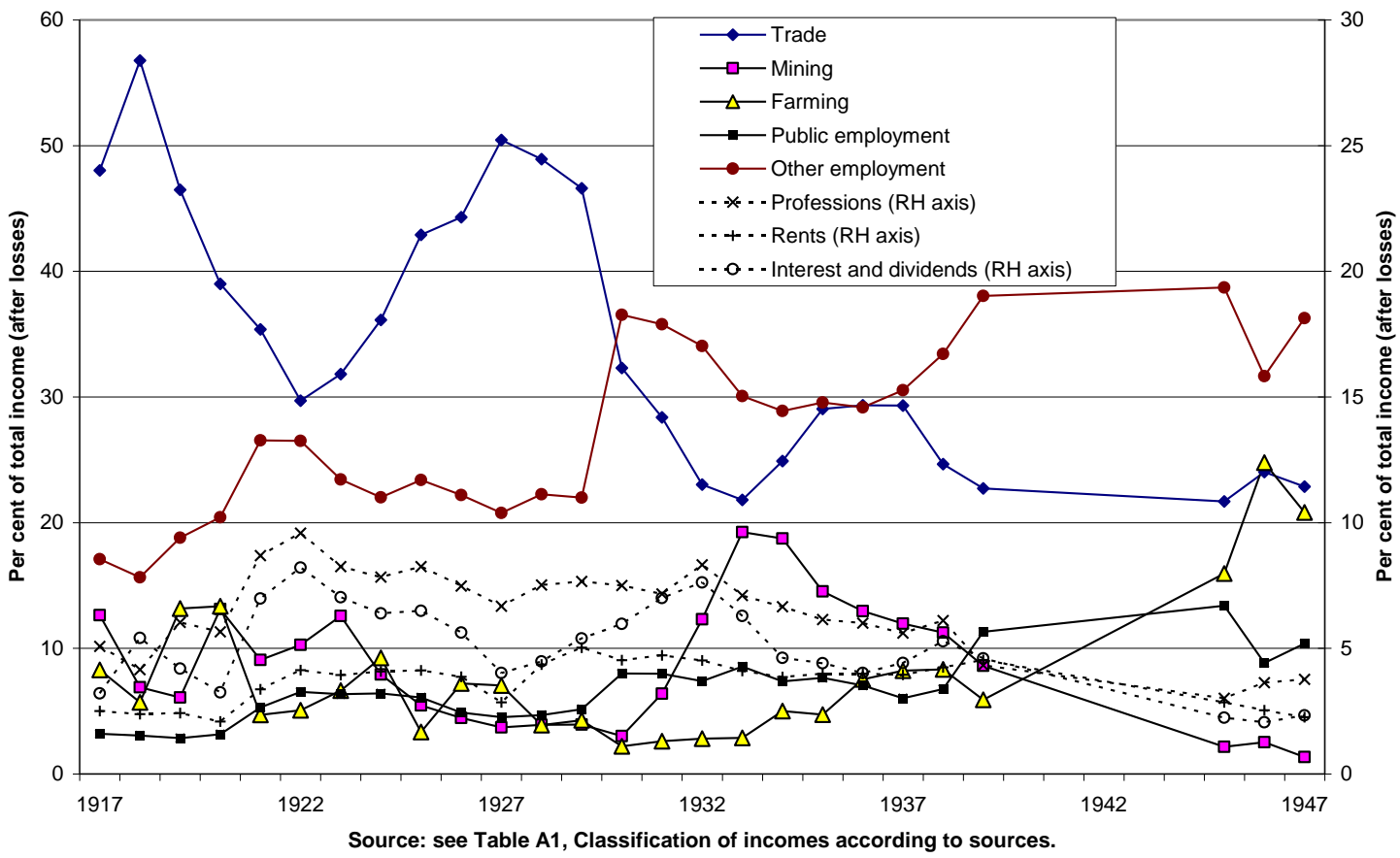


Figure 5 Main source of income of taxpayers Zimbabwe 1963 to 1984

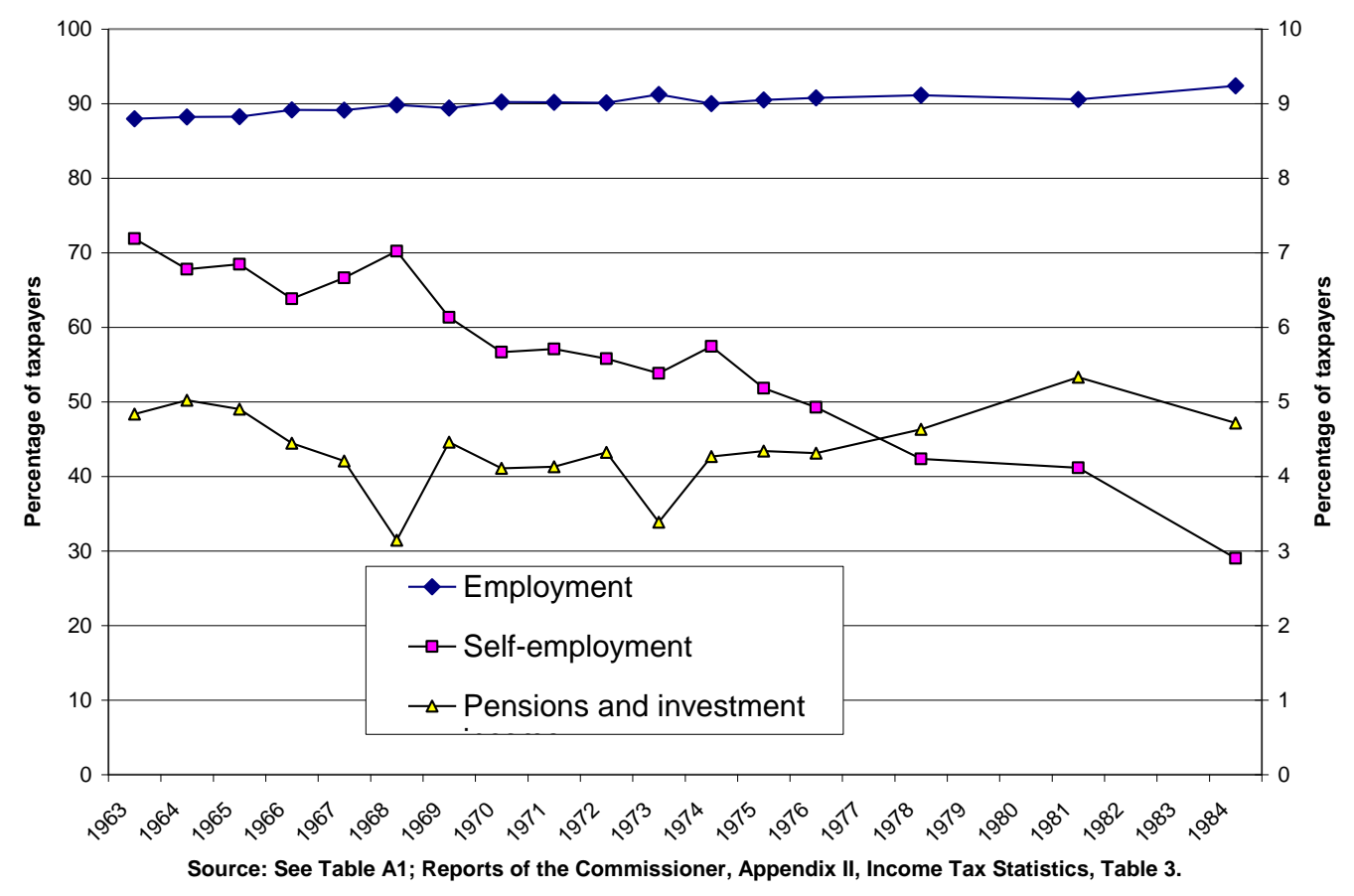




\section{The upper tail of the distribution}

In order to investigate the distribution of income, we need information about income taxpayers by ranges of income. For the three countries, we have data for the years 1938, 1945, and 1953 to 1980 for Nyasaland/Malawi, for 1929 to 1937 and 1943 to 1970 for Northern Rhodesia/Zambia, and 1917 to 1939 and 1945 to 1984 for Southern Rhodesia/Zimbabwe. There are, allowing for a number of gaps, a total of 119 observations.

I begin with the shape of the upper tail of the distribution. The tail is often assumed to take the form of a Pareto distribution, and this is indeed a convenient point of departure. From the control total for tax units derived in Section 3 , we can define the cumulative distribution, $F$, and for each value of $F$ identify the percentile point, $y(F)$, and the average income, $\mu(F)$, above this point. The ratio of $\mu(F)$ to $y(F)$ is then defined as $M(F)$. $M(F)$ is by definition greater than 1. Where the Pareto distribution has a Pareto upper tail, $M(F)$ is a constant, equal to $\alpha /(\alpha-1)$, where $\alpha$ is the Pareto coefficient. Since a higher value of $M$ corresponds to the case where the distribution is more concentrated (the people above you have on average more income), it is more informative to look at $B=\alpha /(\alpha-1)$, referred to as the inverse Pareto coefficient.

Let us assume first that the distribution does have a Pareto upper tail, so $M$ is constant. Its value, $B$, can then be estimated from the relative shares of different income groups within the taxpaying population. If for example $\mathrm{S}_{01}$ denotes the share of the top 0.01 per cent, and $\mathrm{S}_{05}$ the share of the top 0.05 per cent, then the Pareto assumption implies that $B=L N(5) / L N\left(S_{05} / S_{01}\right)$. (The factor 5 comes because we are considering one group that is a fifth of the other.) In Zimbabwe in 1918, the top 0.01 per cent had 51.3 per cent of the income of the top 0.05 per cent. Applying the formula, the value of $B$ is 2.41 . People higher up had on average 2.41 times as much income. It is this value that is shown by the first black diamond in Figure 6 .

The values of the Beta coefficients for the three countries over the full period are shown in Figure 6, where the legend indicates the income groups from which they are calculated. The first conclusion is that the value of 2.41 just calculated for Zimbabwe was unusual. Except for the first part of the 1920s in Zimbabwe (and two isolated observations for the other countries), the coefficient was less than 2 , indicating that people looking up the distribution would have seen that, on average, those above had incomes less than 100 per cent higher than their own. Beta coefficients less than 2 correspond to Pareto coefficients in excess of 2 . In 1951, Colin Clark summarised "all available" Pareto coefficients (1951, pages 533-537). He listed 152 estimates from 23 countries, and of these only 20 exceeded 2 . The highest value recorded by Clark for a was 2.46 in New Zealand, which corresponds to $B=1.68$. At the end of the 1930s, the Beta coefficient in Zambia and Zimbabwe was of this 
order - around 1.65 to 1.75 - and was even lower in Malawi. By these international standards of the time, concentration was relatively low.

What is more, the Beta coefficients were falling over time in a number of periods. For the pre-Federation period, we have little evidence for Malawi, but the coefficients fell steadily over the pre-war period in Zimbabwe and, to a lesser extent, in Zambia. The fall in Zimbabwe stalled during the war, but the overall reduction in concentration was substantial: from 2.29 for the coefficient calculated using the share of the top 0.01 in the top 0.05 , averaging 1918-1920, to 1.60 in 1953. The fall was less than in some European countries over the same period. For example, in Sweden the coefficient fell from 2.65 (averaging 1919 and 1920) to 1.68 in 1953 (source: World Top Incomes Database). But it represented a major change.

Over the period of the Federation, the Beta coefficients fell in all three countries. In Zimbabwe, the coefficient fell from 1.60 in 1953 to 1.45 in 1963, a similar fall to that in Sweden (which went from 1.68 to 1.55). Figure 6 shows that for Malawi, the coefficient calculated using the share of the top 0.01 in the top 0.05 per cent fell from 1.76 in 1953 to 1.44 in 1964. The fall in Zambia was even larger: from 1.79 in 1953 to 1.36 in 1963. As a result, the implied Pareto coefficients were high - indicating low concentration - by international standards: 3.2-3.3 in Zimbabwe and Malawi and 3.8 in Zambia. These striking results must though be qualified by the fact that the estimates, like all those discussed in this section, relate to income excluding dividend payments. The results including dividends may be different, as may be seen from the period when there are data from the supertax. In the case of Zambia, there is a definite fall in the Beta coefficient for the supertax figures: from 1.80 in 1953 to 1.52 in 1961. But for Zimbabwe, the picture is more mixed. With the supertax, the coefficient calculated, as above, using the share of the top 0.01 in the top 0.05 per cent shows little change over the period, but the coefficient based on the share of the top 0.05 in the top 0.1 per cent fell from 1.71 to 1.58. The differential findings at different points in the distribution are taken up below. (For Malawi the number of supertaxpayers is small.)

Before leaving the Federation period, we may note that in 1953 the degree of concentration was higher in Malawi and Zambia (1.76 and 1.79) than in Zimbabwe (1.60), but that the countries tended to converge over the next ten years. As may be seen from Figure 6, they were quite tightly clustered. The degree of similarity is perhaps surprising, given the differences between the countries in the structure of their economies, the extent of settler population, and past histories.

What happened after the end of the Federation? For Zambia, there is only one post-independence observation, which shows a higher coefficient for 1968 than for 1963, but little significance should be attached to this. For Malawi, there is evidence from independence in 1964 to 1979. From Figure 6, 
it may be seen that the Beta coefficient in Malawi increased up to 1977, rising back towards 2. In Zimbabwe, the Beta coefficient rose following UDI in 1965, but then fell in the 1970s. The coefficient calculated from the share of the top 0.05 per cent in the total of the top 0.1 per cent (not shown in Figure 6) in 1984 , the last year for which there are data, was as low as 1.41, corresponding to a Pareto coefficient of 3.44. At this time, independent Zimbabwe had a low level of concentration at the top by international standards. Of the 21 Beta coefficients given by Atkinson, Piketty and Saez (2011, Table 6) for different countries around 2005, only those for China and the Netherlands are below 1.5.

From the Beta coefficients we can, therefore, learn about the long-run changes at the top of the distribution and about the differences between countries, but how far do the conclusions depend on summarising the shape of the upper tail in a single parameter (the inverse Pareto coefficient)?

How close is the upper tail to Pareto in form (is $M(F)$ a constant)?

The validity of assuming a Pareto distribution depends on the purpose at hand. It is for example commonly employed to interpolate tabulated data over ranges, in place of the split histogram method used here (as described above). For this purpose the Pareto coefficient is only assumed to be constant in an interval, and it does not matter if the coefficient changes between intervals. On the other hand, if we are seeking to make a general statement about the degree of concentration, as with the Beta coefficients used above, then we have to ask how far the distribution can be adequately summarised by a single parameter. If we were to seek to explain the movements over time (or the differences across countries) by differences in economic structure, or by other variables, would we be missing important elements if we take a single coefficient based on one part of the distribution (like the share of the top 0.01 within the top 0.05)?

One test of the overall validity of the Pareto assumption is provided by the evaluation of the coefficient using different income shares, as for the two shown in Figure 6. This suggests at first sight that the two series move closely together, but closer examination reveals a more nuanced picture. If for example we take the changes in Zimbabwe during the Federation period, we have:

Beta coefficient from

Share of top 0.005 in top 0.01

Share of top 0.01 in top 0.05

Share of top 0.05 in top 0.1

Share of top 0.1 in top 0.25

Share of top 0.1 in top 1
1953

1.53

1.60

1.70

1.83

1.87
1963

1.44

1.45

1.47

1.47

1.46 
The coefficients shown in Figure 6 are indicated in bold, and we can see immediately that the values for 1963 would be little affected if we had looked instead at the share of the top 0.05 per cent in the top 0.1 per cent, or had ventured down to the top 1 per cent. But the values for 1953 are quite different, and indicate a different extent of change over time. Earlier the change in Zimbabwe was described as similar to that in Sweden. The Swedish figure for the Beta coefficient was based on the share of the top 0.1 in the top 1. Basing the Zimbabwean figure on this comparison rather than on that used earlier, we would conclude that the fall in concentration is much larger than in Sweden over the same period.

What this shows is that there has been a change in the shape of the upper tail. This may be seen by plotting the $M$ curves for Zimbabwe in the two years, as in Figure 7. The curve for 1963 is close to horizontal, but that for 1953 has a pronounced downward slope. A least squares fit to the data for 1953 yields an equation

$$
\begin{gathered}
1.521+2.814 x-4.991 x^{2}, \quad R^{2}=0.995 \\
(0.135)(0.417)
\end{gathered}
$$

where $x$ denotes $(1-F)$ measured in per cent, and the standard errors are shown in brackets. There is a significant quadratic slope to the $1953 \mathrm{M}$ curve. ${ }^{6}$ In contrast, the coefficients of $x$ and $x^{2}$ are insignificant in the case of 1963, confirming that it is horizontal.

Differences in the shape of the distribution emerge also when we compare countries. Figure 8 shows the M curves for 1963 (1964 in the case of Malawi). For Zambia, like Zimbabwe, the curve is close to flat over much of the range. For Malawi, in contrast, there is a strong downward slope. Examination of the $M$ curve places therefore a rather different complexion on the earlier conclusion that the three countries had converged by the end of the Federation. This was true at the very top, but the approach to the top was different - steeper - in the case of Malawi.

\section{Conclusions}

Concentration within the top income group, as summarised by the Beta coefficient, was falling over the colonial period, in the 1930s in the Rhodesias, and in the Federation period in all three countries (subject to the qualification concerning dividend income). At the time of independence (or UDI), the degree

\footnotetext{
${ }^{6}$ By integrating the quadratic, an explicit form for the distribution can be derived - see Atkinson (2014). It is a modified form of the Pareto distribution.
} 
of concentration was relatively low, corresponding to Pareto coefficients in excess of 3. In Malawi, concentration increased after independence; in Zimbabwe, it first increased and then fell, reaching a low level in the early 1980s. At the same time, more detailed examination of the shape of the distribution suggests a more nuanced picture. In order to fully understand the changes over time, and the differences between countries, we need to examine the $M$ curves and recognise that the upper tail cannot always be adequately described by a single parameter. 
Figure 6 Beta coefficients Central Africa

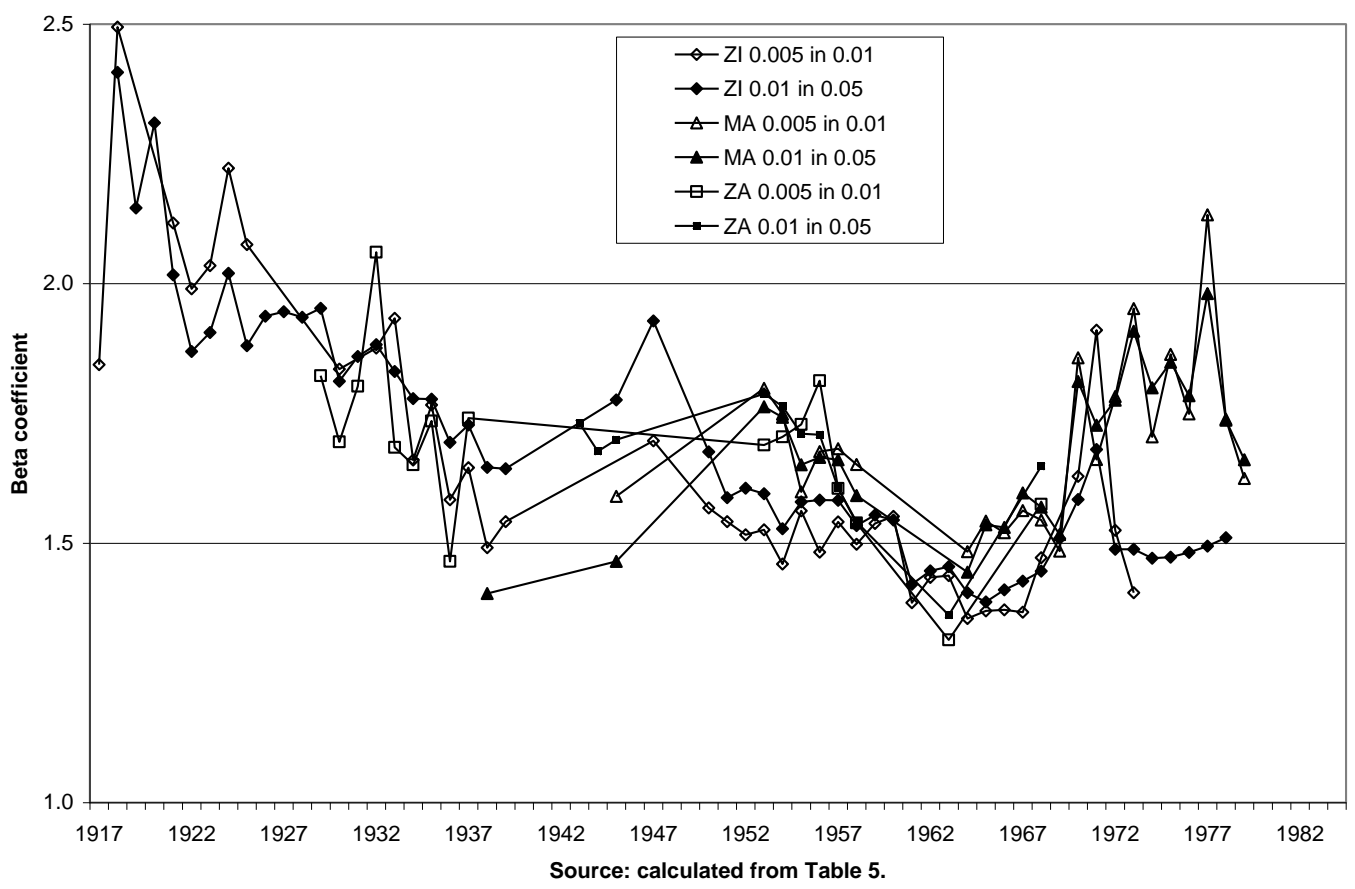

Figure 7 M curves for Zimbabwe 1953 and 1963

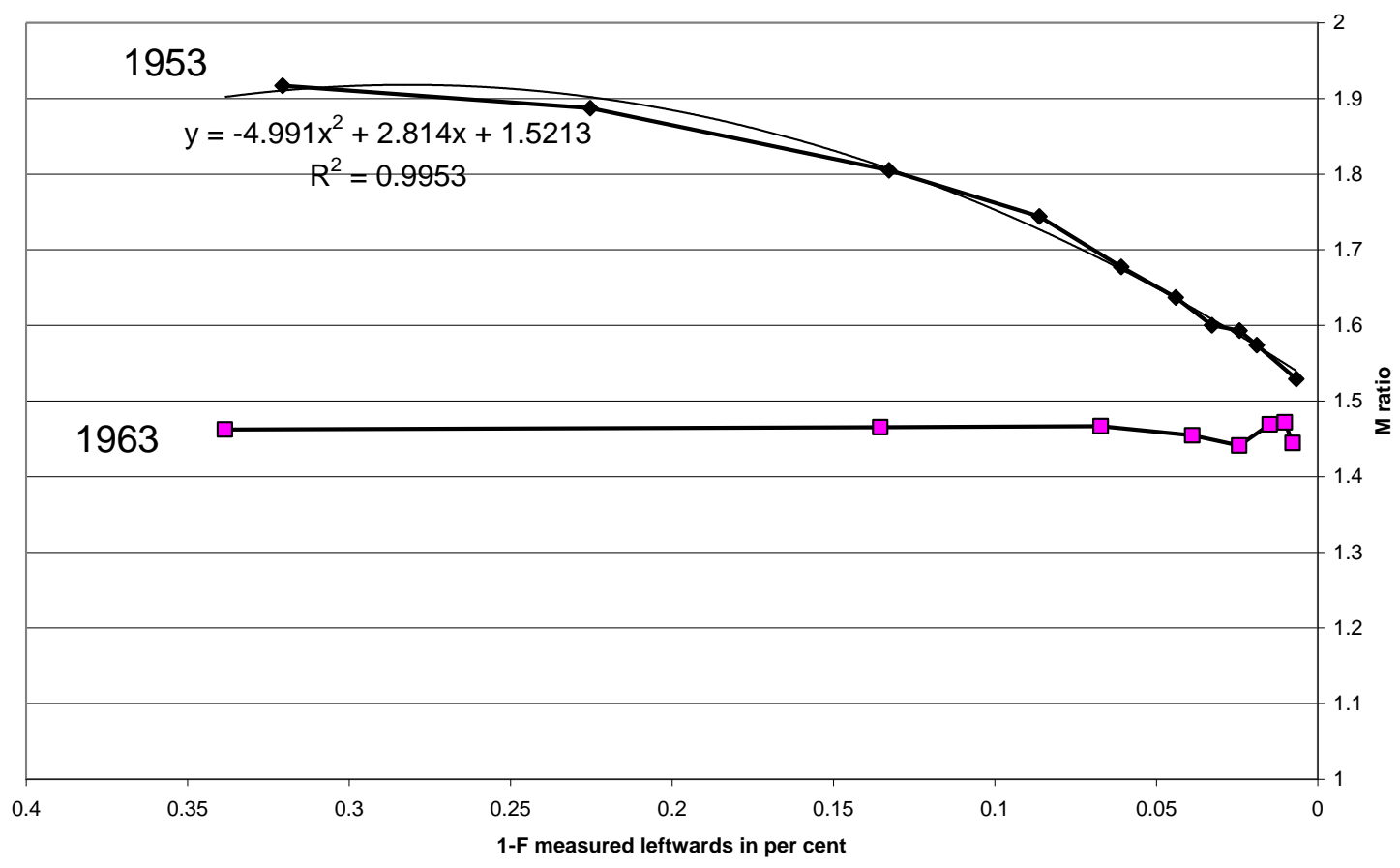


Figure 8 Comparison of M curves in three countries in 1963 (1964 for Malawi)

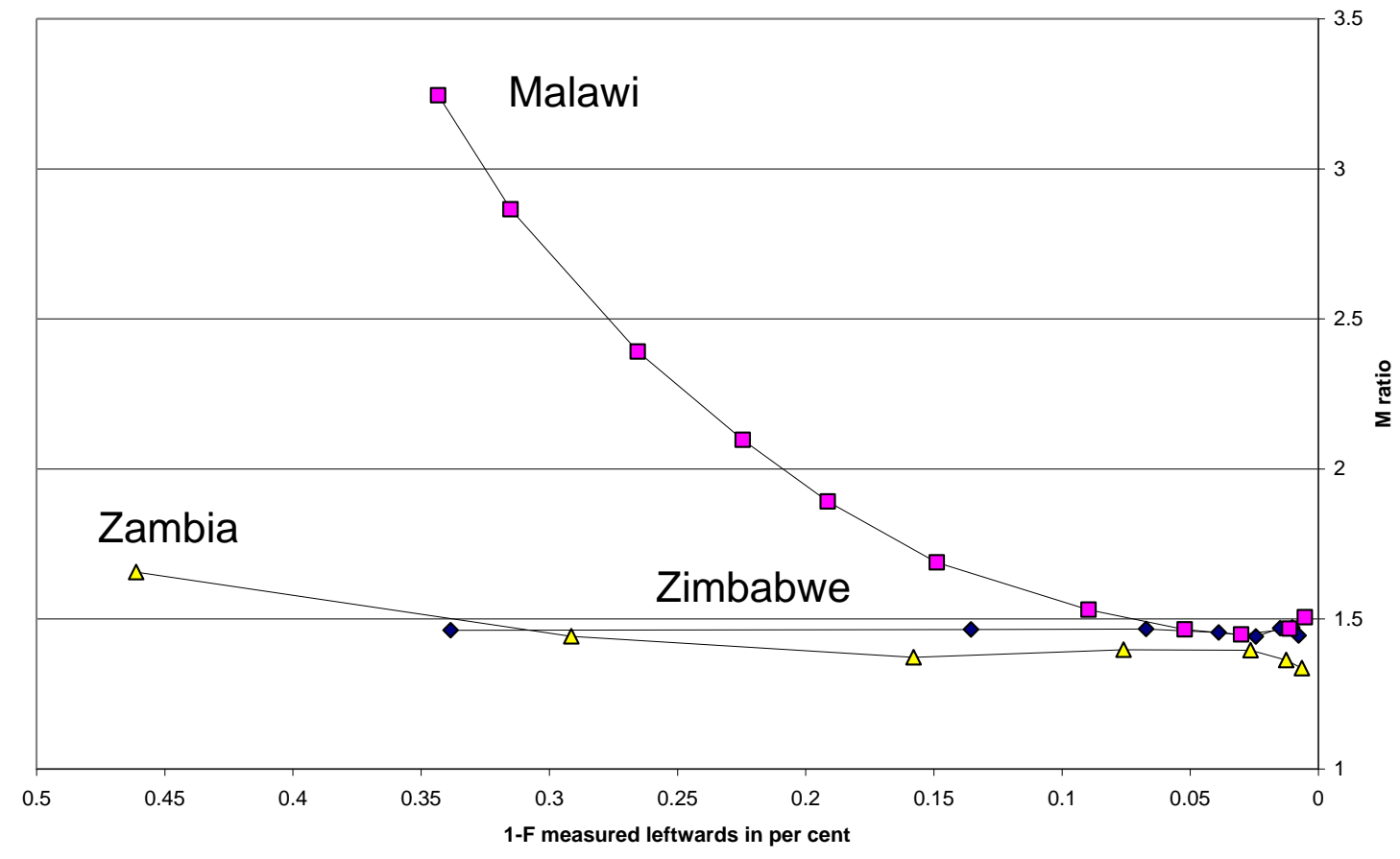




\section{Control totals for income}

So far we have looked at the distribution among income taxpayers. We now consider the shares of income received by the well-off relative to the total income of all citizens. The affluence among top income receivers may be quite generally shared (there may be a low value for $M(F)$ ), but as a group they may be much more privileged. The role of the different elements may be seen from the fact that the share, $S$, of the top $(1-F)$ per cent of the population, commencing at an income $y$, is given by

$$
S /(1-F)=M(F) \cdot(y(F) / \mu)
$$

where $\mu$ is the mean income. A relatively even distribution among the elite (a low value of $M$ ) may still be associated with a high degree of overall inequality where the entry level $(\mathrm{y}(\mathrm{F}))$ is high in relation to mean incomes.

It is indeed the case that, as we shall see, variations in the entry "price" may be more powerful determinants of the income shares. At the same time, the estimation of the mean income, $\mu$, for the countries considered here poses a major data challenge. The difficulties in calculating national income in Africa are widely recognized, and there is much criticism of contemporary macroeconomic statistics. The first reaction of readers may therefore be that the estimation of incomes per head for colonial Africa is a hopeless task. However, the situation is not that desperate. Work on national accounts in a number of African colonies developed at much the same time as official national accounts were coming into use in OECD countries. This owed much to two pioneers: Herbert Frankel (and his colleague, Herzfeld) and Phyllis Deane. Already in 1945, Frankel (1945) published estimates of national income for Zimbabwe (Southern Rhodesia) covering the years 1924 to 1943 (cited in Shaul, 1960). Deane (1948 and 1953) produced income totals for Zambia (Northern Rhodesia) and Malawi (Nyasaland). It is their work that underlies the estimates of the income control totals employed here, as is described below for each country.

\section{Malawi}

The control total used here is constructed by starting with the UN series for Gross National Income (GNI) in million Kwacha (available from 1970) and work backwards, by linking to earlier series for GNI or GDP. (The Kwacha was introduced in 1971, at the rate of $2 \mathrm{Kwacha}=£ 1$.) The first of these linked series is that from the Statistical Yearbook (SY) 1976, page 189, linked at 1970. The estimates for 1964 to 1973 were on the former SNA basis, and the linking involves a large up-rating by some 35 per cent. The second series is from Republic of Malawi, National Accounts Report (1964-67), Table 12, sum of 
monetary GDP and subsistence production, linked at 1964. This linkage back to 1954 involves raising the earlier estimates by a further 52 per cent. The final link is to Table 94 in Central African Statistical Office, National accounts and balance of payments of Northern Rhodesia, Nyasaland and Southern Rhodesia, 1954-1963, which gives estimates for NDP 1950 to 1954 based only on the monetary economy, coupled with a comparable version of the estimates by Deane for 1938, 1945 and 1948.

Gross National Income does not correspond to total household income. Adjustments have to be made for retained corporate profits, for the profits of public corporations, and for government interest and transfers received by households. The earlier income-based national accounts included tables for personal incomes. Table 95 in Central African Statistical Office, National accounts and balance of payments of Northern Rhodesia, Nyasaland and Southern Rhodesia, 1954-1963, shows for Malawi the total of wages, gross income from unincorporated enterprises, and personal income from property. The average over the ten year period was 92 per cent of gross national income (GNP at factor cost), and this proportion has been assumed throughout.

\section{Zambia}

Deane (1948 and 1953) identified two important considerations in the Zambian context. The first is the difference between domestic and national product arising from the mining activities that developed in the 1920s. Her estimates for 1938 show the total domestic (territorial) income as $\mathbf{f 1 3 . 5}$ million, but the total national income as $\mathbf{f} 8.5$ million. The second is the importance of subsistence agricultural output, estimated to be some $\mathrm{f1.9}$ million for 1938.

In reaching the control total used here, we begin with the UN figure for Gross National Income (GNI) in million Kwacha in 1970 (1,158 m Kwacha) and work backwards, by linking to earlier series for GNI(GNP). (The Kwacha was introduced in 1968, at the rate of $2 \mathrm{Kwacha}=\mathrm{f1}$.) The first of these series is that from the Republic of Zambia, National accounts and input-output tables 1973, page 13, from which are obtained estimates for 1965 to 1970. These were on the former SNA basis, and the linking involves an up-rating by 12.9 per cent. The second series is from Republic of Zambia, National accounts 1964-68, Table 1, linked at 1965 and at 1964. These two linkages back to 1954 involved raising the earlier estimates by 7.2 per cent. (The 1955 figure comes from National accounts and balance of payments of Northern Rhodesia, Nyasaland and Southern Rhodesia 1954-1963, Table 50.) The series for 1945 to 1953 is from Borland and Irvine (1954, Table 1). In considering how to link these series, bridging 1953 to 1954, it was calculated that of the $\mathrm{E} 12.2$ million difference between GNP at factor cost (GNI) in 1953 and in 1954, E9.4 million was due to the higher allowance for the African subsistence production. Since the 1945 to 
1953 national accounts referred to the figure as purely "nominal", the two series have been linked by adding that amount to the 1953 figure and adjusting the earlier figures proportionately.

The early national accounts included tables for personal incomes. Table 7 in Borland and Irvine (1954) shows that personal income, including transfer incomes, averaged some 64 per cent of net national income over the period 1945 to 1953 . A less complete calculation, not including transfers for the period 1954 to 1964 gives an average of 67 per cent (source: Republic of Zambia, National accounts and balance of payments of Zambia 1954-1964, Table 2). The latter figure is too low, since transfers are omitted, and the former figure may understate the value of subsistence production. In view of this, a figure of 70 per cent of $\mathrm{GNI}$ is employed here as the income control total.

The figure for 1938 for household income is obtained from National accounts and balance of payments of Northern Rhodesia, Nyasaland and Southern Rhodesia 1954-1963, Table 46 as $\mathrm{E} 11.4$ million, with the subtraction of $\mathrm{f} 5.8$ million company incomes from Deane (1948, page 32 ) and $\mathrm{E} 0.2$ million government income from property (Deane, 1948, page 120). To this is added f4.4 million African subsistence income, a figure reached by applying the same per capita figure as in 1945 ( $€ 2.16$ per person per year), which seems more comparable with the later estimates than the $\mathrm{f} 1.8$ million given by Deane (1953, page 64). The total household income for 1938 is then $\mathrm{f} 9.8$ million.

This leaves the derivation of totals for the intervening years 1939 to 1944, and for years prior to 1938 (the years 1929 to 1937). Simple interpolation seems unsatisfactory in view of the variation in the output of the copper industry, which grew from negligible size in the 1920s to represent a major part of the economy: from 1920 to 1960 "the copper industry transformed Northern Rhodesia from a comparatively stationary economy into a rapidly growing one" (Baldwin, 1966, page 40). However he goes on to describe it as a "dual economy", with the industry existing in the midst of a subsistence economy. If we take seriously the description by Baldwin, then total income is additive. Total household income, Y, may be represented by adding (1) a per capita allowance, $\pi$, for the subsistence income (where the figure of $£ 2.16$ per head is taken) plus the taxable income in 1929 (when copper output was negligible) to (2) the contribution, X, of copper output (source: Mitchell, 1982, page 308) valued at the world price (source: US Geological Survey Data Series 140). It was found by trial and error that setting the latter element as $0.0249 \mathrm{X}^{1.463}$ gave a reasonable fit, when combined with (1), to the data for 1938 and 1945 to 1964 - see Figure 9 - and the total is used to predict the years 1929 to 1937 . At the same time, use of the symbol $\pi$ should not provide any false sense of certainty. The difference between the figure used for 1938 (£2.16) and that implied by Deane's estimate of subsistence income ( $\mathrm{E0.88)}$ is 
indicative of the margin of error surrounding the income control totals for these earlier years.

\section{Zimbabwe}

The more developed state of national accounts means that for Zimbabwe a different, and more direct, approach can be followed. The published national accounts provide from 1954 an income side account that can be used to calculate total household income as the sum of wages and salaries, gross income from unincorporated enterprises, and personal income from property. For example, in 1954, this gave a total of $£ 133.3$ million, which was 82.1 per cent of Gross National Income. The income from unincorporated enterprises includes the production by rural households for own consumption, where this is produce either directly consumed or produce sold or bartered within the rural household sector. The income from unincorporated enterprises and from wages and salaries is shown separately for Africans and for "Europeans, Asians and Coloureds". In 1954, the latter group received 56 per cent of total income. The totals for 1954 to 1978 are taken from National accounts and balance of payments of Rhodesia, for the years 1965, 1966, 1967, 1968 and 1969 (in each case Table 2), 1974 (Table 24), 1976 (Table 34) and 1978 (Table 29). The figures from 1978 to 1984 were extrapolated on the basis of Gross National Income from National Income and Expenditure Report 1992, Table 1.1. The Rhodesian/Zimbabwean dollar $\$ Z$ was introduced in 1968 at the rate of $2 \$ Z=\mathrm{E} 1$.

The totals for years before 1954 are obtained by assuming that total household income moved in line with net domestic product in the monetary economy, making use of the estimates of the Central Statistical Office (from 1939 to 1953) and Frankel (1924 to 1938), from National accounts and balance of payments of Rhodesia 1973, Table 1. (The series for GDP at factor cost is used to link 1953 and 1954.) For the year 1942, a comparison may be made with the income total estimated by the Government Statistician (Frankel, 1945, Table 2), which is $£ 27.0$ million (excluding the income of companies and the imputed rental value of owner occupied houses). This is close to the total reached here (£29.8 million).

It remains to arrive at income totals for the years 1917 to 1923 . As was observed by Frankel, there was in the inter-war period a close relationship between the value of exports and the value of national income: "the correspondence is so close that one would normally be justified in attempting to forecast the size of the Rhodesian National Income on the basis of the future movements of exports" (1945, para 8). A major part of the exports was constituted by gold. If we take gold output (from Mitchell, 1982, pages 316317 ), valued at the ruling gold price, to construct an index of the value of gold 
production, $X$, then over the period 1924 to 1939 the value of national income, $\mathrm{Y}$, is linearly related to $\mathrm{X}$

$$
\mathrm{Y}=7.86+0.783 X \quad \mathrm{R}^{2}=0.65
$$

The fit is not outstanding, but seems sufficient to make estimates for the years 1917 to 1923.

\section{Conclusions}

The resulting control totals for household income are given in Table 1. The implied average annual income per tax unit is shown in Figure 10 (in money terms, with no adjustment for changes in the price level). The potential margins of error in the control totals should be evident from the description given above of the different stages in their construction. The assumptions regarding the proportion of household income are at best an approximation. The successive up-ratings of GDP at different revisions may have been in the correct direction, but the applications of the correction factors to earlier years represent a sizeable departure from the published figures. The estimates themselves are surrounded by wide margins of error. The early estimates of national income were accompanied by an evaluation of their "assessed accuracy" (Irvine, 1955, page 366). The gradings were attached to individual items, and not to the total, and ranged from a) believed to be accurate within 5 per cent, for wages and salaries, to d) accuracy \pm 25 per cent, for African income from unincorporated enterprise, and e), denoting a "nominal estimate with unknown error", in the case of African subsistence income. These qualifications must temper the conclusions about top income shares drawn in the next section. 
Figure 9 Total household income and predicted income Zambia

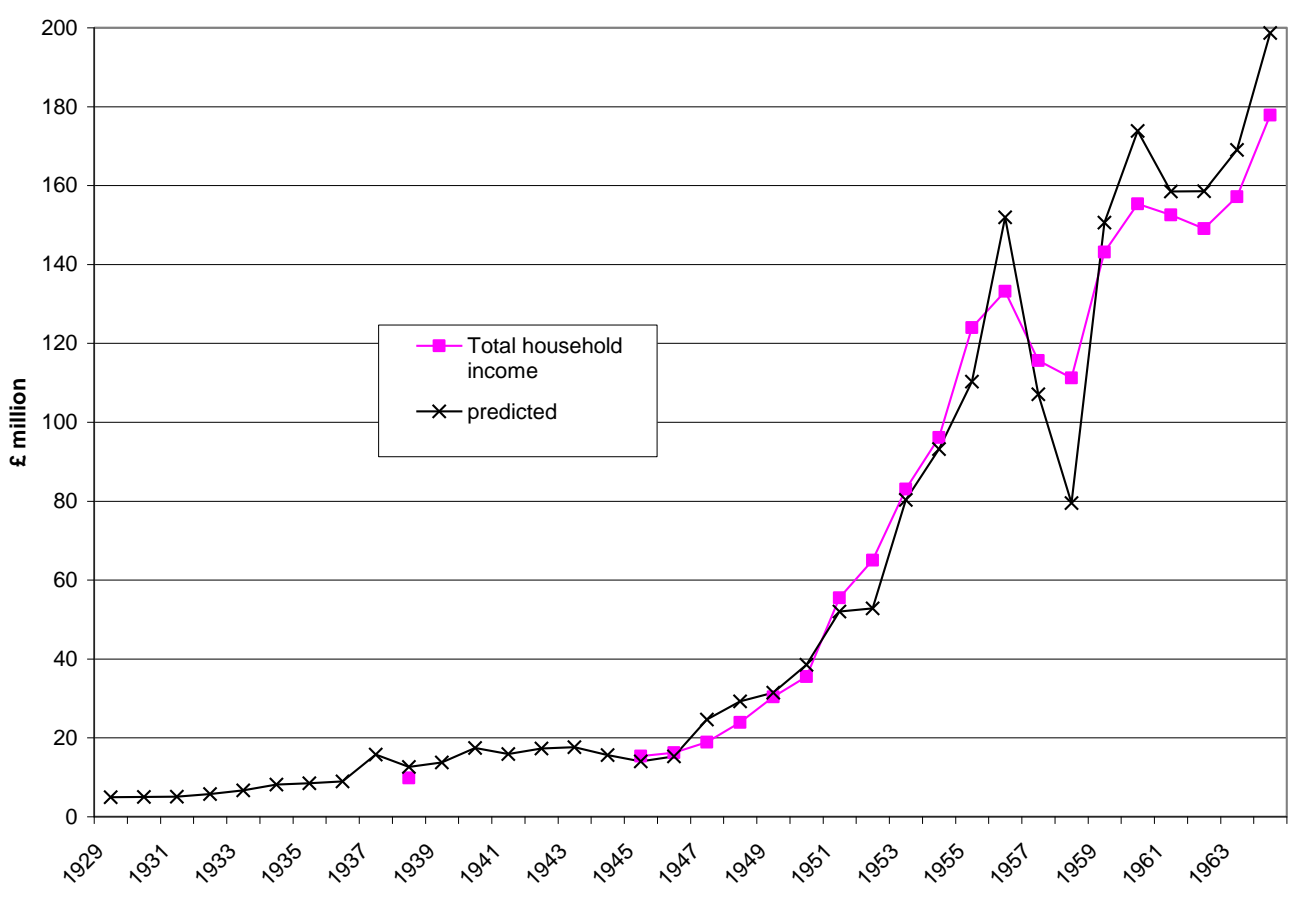

Figure 10 Annual income per tax unit

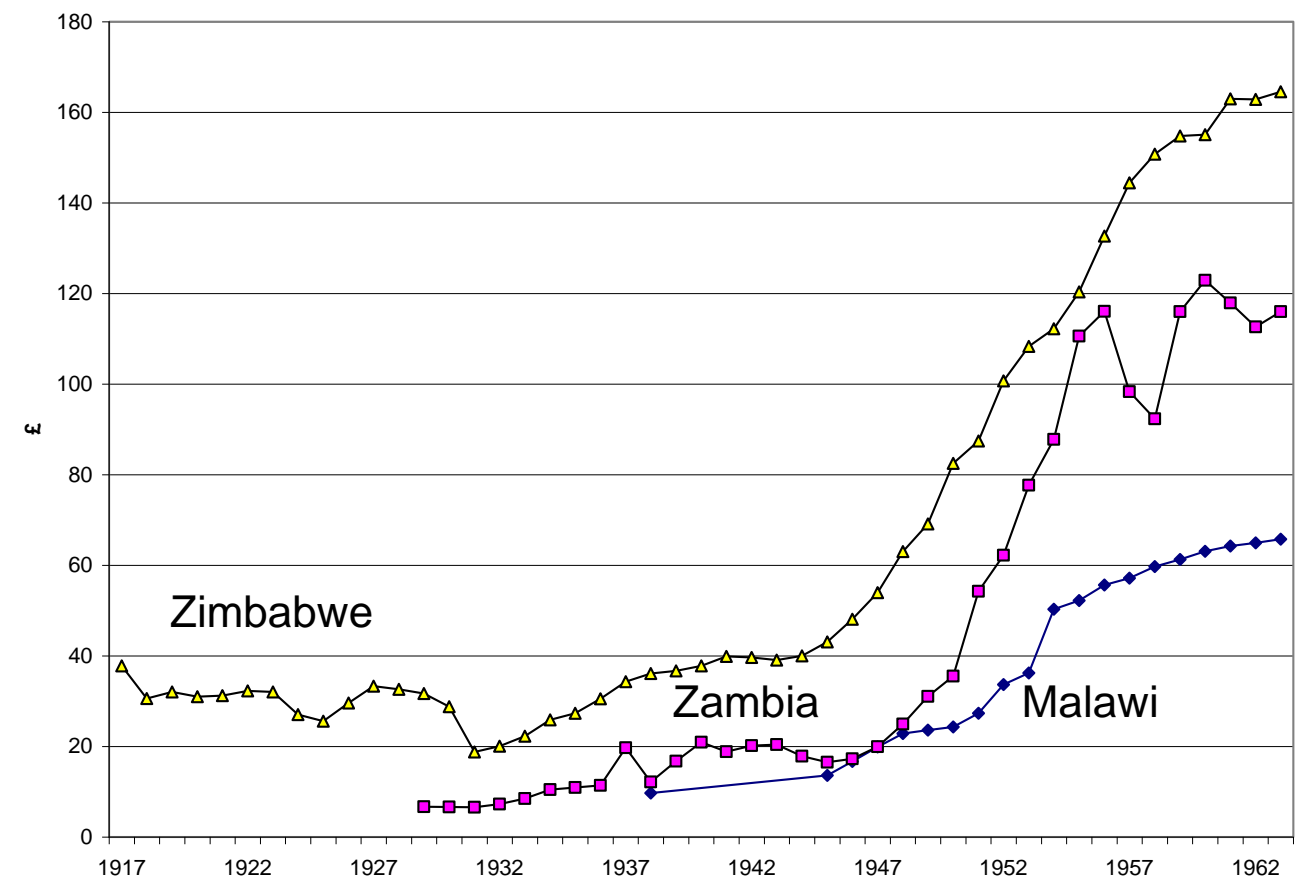




\section{Top income percentiles and shares}

The ratio of the income share to the population share is equal to $M$ times the threshold (expressed relative to the mean). We have seen the tendency for $M$ to fall in the pre-war period and in the 1950s. What has happened to the threshold? Figure 11 shows the top percentiles for the three countries: the amounts required to enter the top 0.1 , top 0.01 and top 0.005 per cent. At the beginning of the 1920 s, one needed some 100 times average income to be in the top 0.01 per cent, and this increased over the decade to reach some 175 times in the early 1930s. This latter figure is a very large multiple by international standards, the average for the US over the period 2003 to 2012 being 122 (from website of Emmanuel Saez, Tables A0 and A4). In Zambia, the high early values are off the chart.

Entry to the top income group was therefore highly restricted in the prewar period. After the Second World War, the top percentiles fell. By the end of the 1950s, the amount required to be in the top 0.01 per cent was some 60 times average income in Malawi, 65 times in Zambia and 80 times in Zimbabwe. These were still high by international standards: the average for the US over the 1950 s was 35 . An income of 35 times the mean only allowed a person to enter the top 0.1 per cent in Central Africa, not reaching the top 0.01 per cent as in the US. For Malawi and Zimbabwe, there is evidence for the period after independence/UDI. In Malawi, there was an initial rise in the top percentiles, but these fell after 1968 up to the end of the 1970s. In Zimbabwe, there was broad stability until the end of the 1970s when the percentiles began to fall.

The high threshold means that, even allowing for the - relatively - low $M$, the colonial top income shares are indeed high. The full set of estimates for income shares are given in Tables $5 \mathrm{~A}$ to $5 \mathrm{C}$, and a selection are plotted in Figures 12 and 13. As a yardstick, we may note that in the US in the 1920s the share of the top 0.1 per cent averaged 6.6 per cent (website of Emmanuel Saez, Table A1). From Figure 12 it may be seen that the corresponding shares were greater in Zimbabwe (from 1927) and Zambia (from 1943), where they exceeded 8 per cent and reached 10 per cent or more for a number of years. In Malawi in 1938 they were close to 8 per cent. As has been stressed, these estimates depend on the control totals, but it would require the income totals to be under-stated by 50 per cent for the colonial shares to be reduced from 10 to 6.6 per cent.

Unless the colonial income totals were too low to such a great extent, it seems safe to conclude that in pre-war British colonial Africa top income shares were high. At the same time, the lower degree of concentration means that the differences become less marked as the very top is approached. If, for 
example, Zimbabwe and the UK are compared in the 1930s, then the average 0.1 share in Zimbabwe is 9.6 per cent, compared with 6.9 per cent in the UK (from World Top Incomes Database). In other words, the share is about 40 per cent higher. But the 0.05 share is 6.7 per cent, compared with 5.0 per cent in the UK, and the 0.01 share is 2.69 , compared with 2.32 in the UK. The latter means that the Zimbabwe share is only some 16 per cent higher, which is within the possible margin of error in the control total - assuming that it is in the direction of being too low.

Over time, the income shares appear to have risen during the Second World War and peaked in the late 1940s. There was then a period when the top shares fell markedly in Zambia and Zimbabwe, although less so in Malawi. The share of the top 0.1 per cent halved in Zambia between 1950 and 1958. The share in Zimbabwe fell from 11.3 per cent in 1950 to 3.8 per cent in 1963. In considering these findings, account has to be taken of the exclusion of dividend income. Where the supertax data can be used, the effects of this omission can be seen, as in Figure 14. The estimates based on supertax data, indicated by dashed lines, are higher, but until the 1960s the differences are not appreciable and the time paths are very similar.

The post-war and Federation period saw a major reduction in shares at the very top, and the same applies when we consider larger groups, including the top 1 per cent, as shown in Figure 13. The top 0.5 share in Zambia fell from 28.4 per cent in 1948 to 14.3 per cent in 1958. This halving of the share was due mostly to the fall in the percentile (the entry price), which went from 33.0 to 20.1 , but also reflected a 17 percent fall in $M(F)$. The Beta coefficient calculated from the share of the top 0.1 in the top 0.25 fell from 1.74 in 1948 to 1.44 in 1958. The top 1 per cent share in Zimbabwe fell from 32.7 per cent in 1950 to 19.0 per cent in 1963. In this case, there was a small contribution from a decline in the percentile, and most of the change was due to the fall in $M(F)$.

What happened after the end of the Federation? After UDI, the top income shares in Zimbabwe rose, but at a moderate rate in that by 1973 the share of the top 1 per cent had increased by some $2 \frac{1}{2}$ percentage points over the previous ten years. The share of the top 0.1 per cent had increased from 3.9 per cent in 1963 to 4.9 per cent in 1973. Rather more marked was the subsequent fall, particularly after 1980. In Malawi, 1973 saw the top shares not greatly different from those in 1964: the share of the top 0.1 per cent was 4.6 per cent in both years. There was then some fall in the top shares from 1973 to 1980.

To sum up, the evidence assembled here shows that at the beginning of the 1980s the top shares in Malawi and Zimbabwe were high by international standards at the time. The share of the top 0.1 per cent was, averaging the figures, 3.6 per cent in both countries, so that this group had 36 times their 
proportionate share. Taking figures from the World Top Incomes Database, averaging 1980 to 1985 (in some cases over 4 years), we see that no country included in this database had a share of the top 0.1 as high as 3.6 per cent. The closest were South Africa (2.9 per cent), Singapore ( 2.8 per cent) and the US (2.5 per cent). The top shares in Central Africa were more than twice those in France, India, Italy, Japan, and the UK, and more than three times those in Australia, New Zealand and Scandinavia. The share of the top 1 per cent in Zimbabwe, averaging over 1980 to 1984 , was 16.6 per cent. The closest were South Africa (11.4 per cent), Singapore (10.5 per cent) and the US (8.4 per cent). 
Figure 11 Percentiles

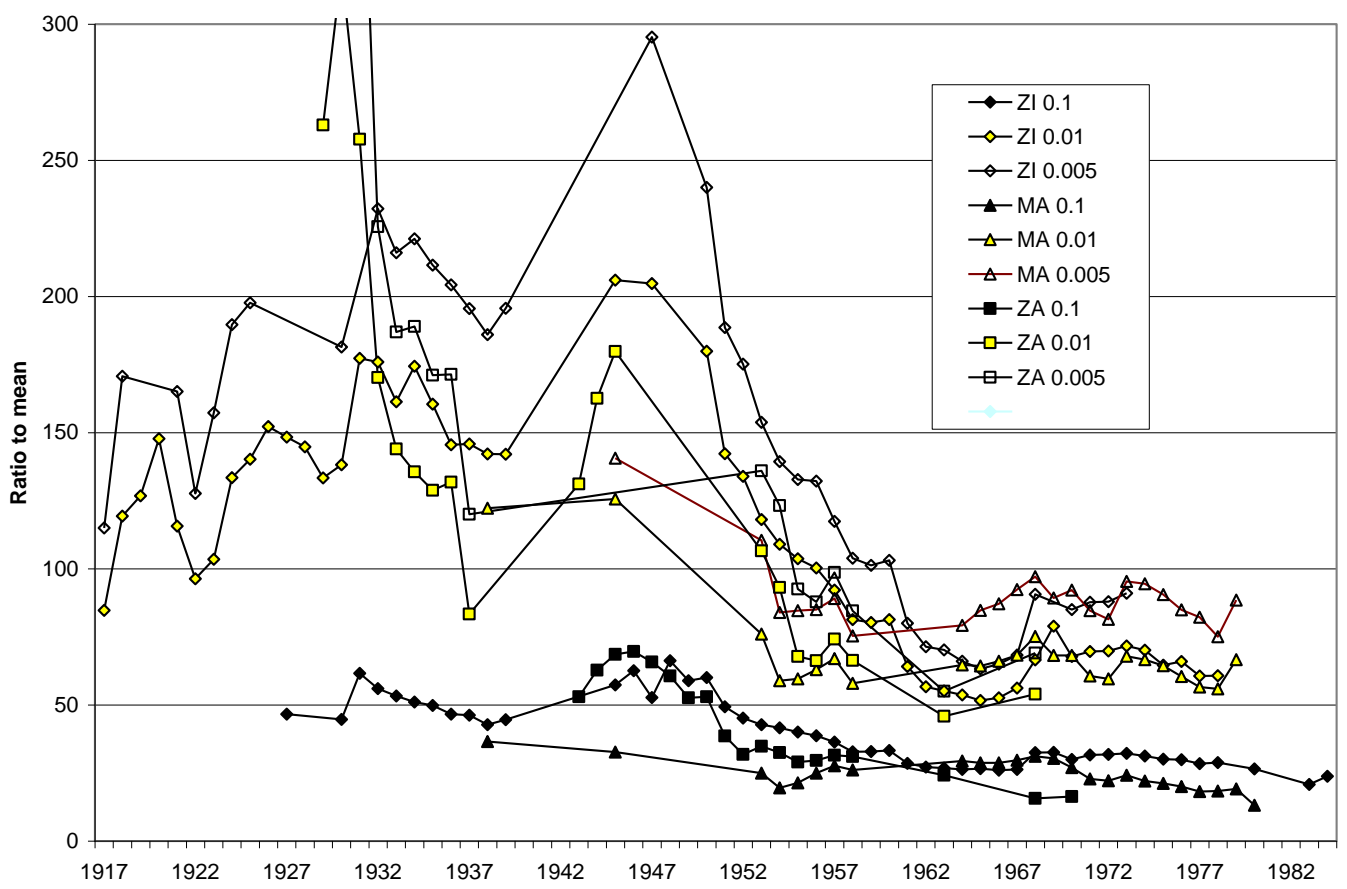

Figure 12 Income shares (top 0.005 to top 0.1 per cent)

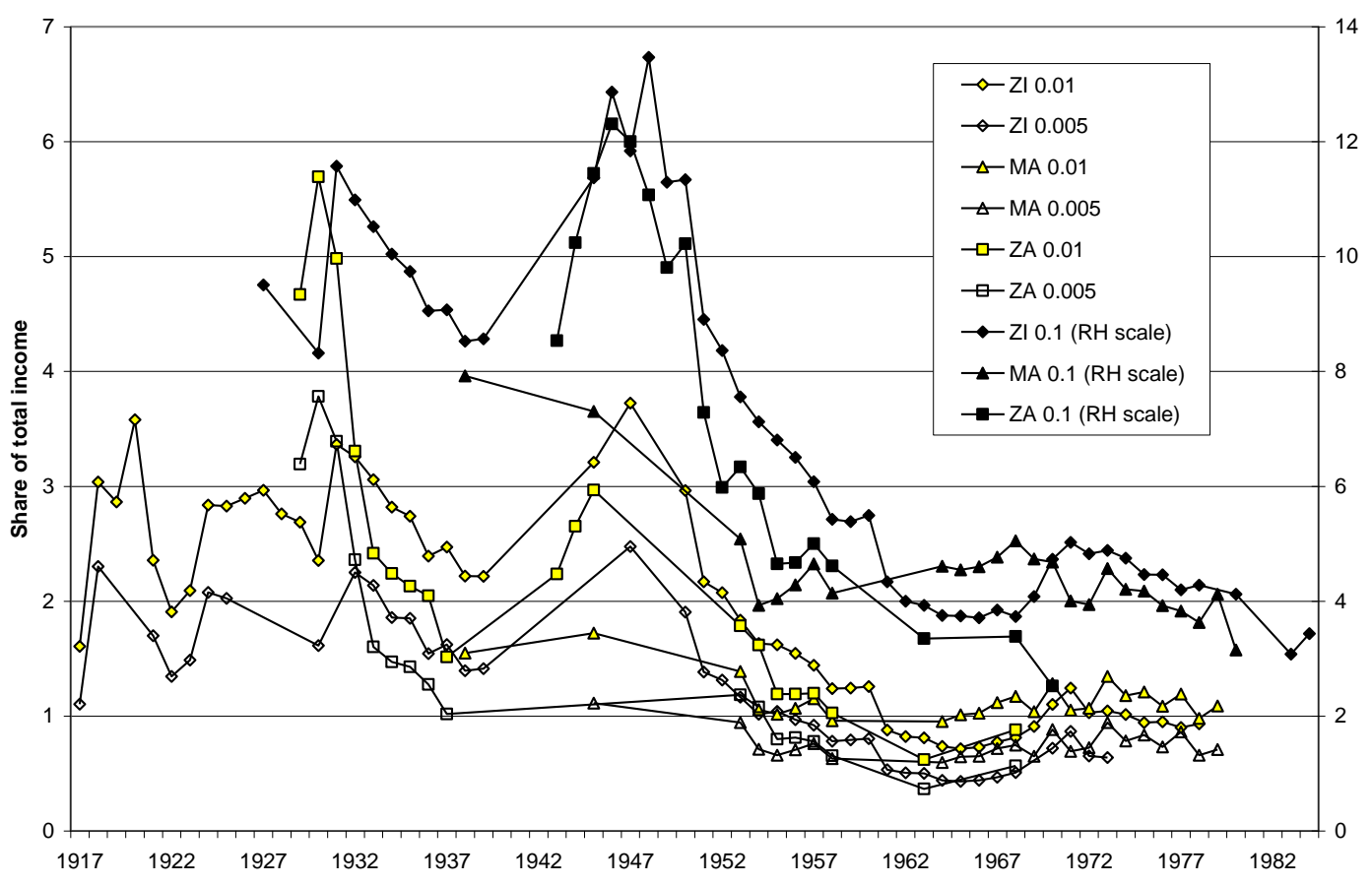


Figure 13 Income shares (top 0.25 to top 1 per cent)

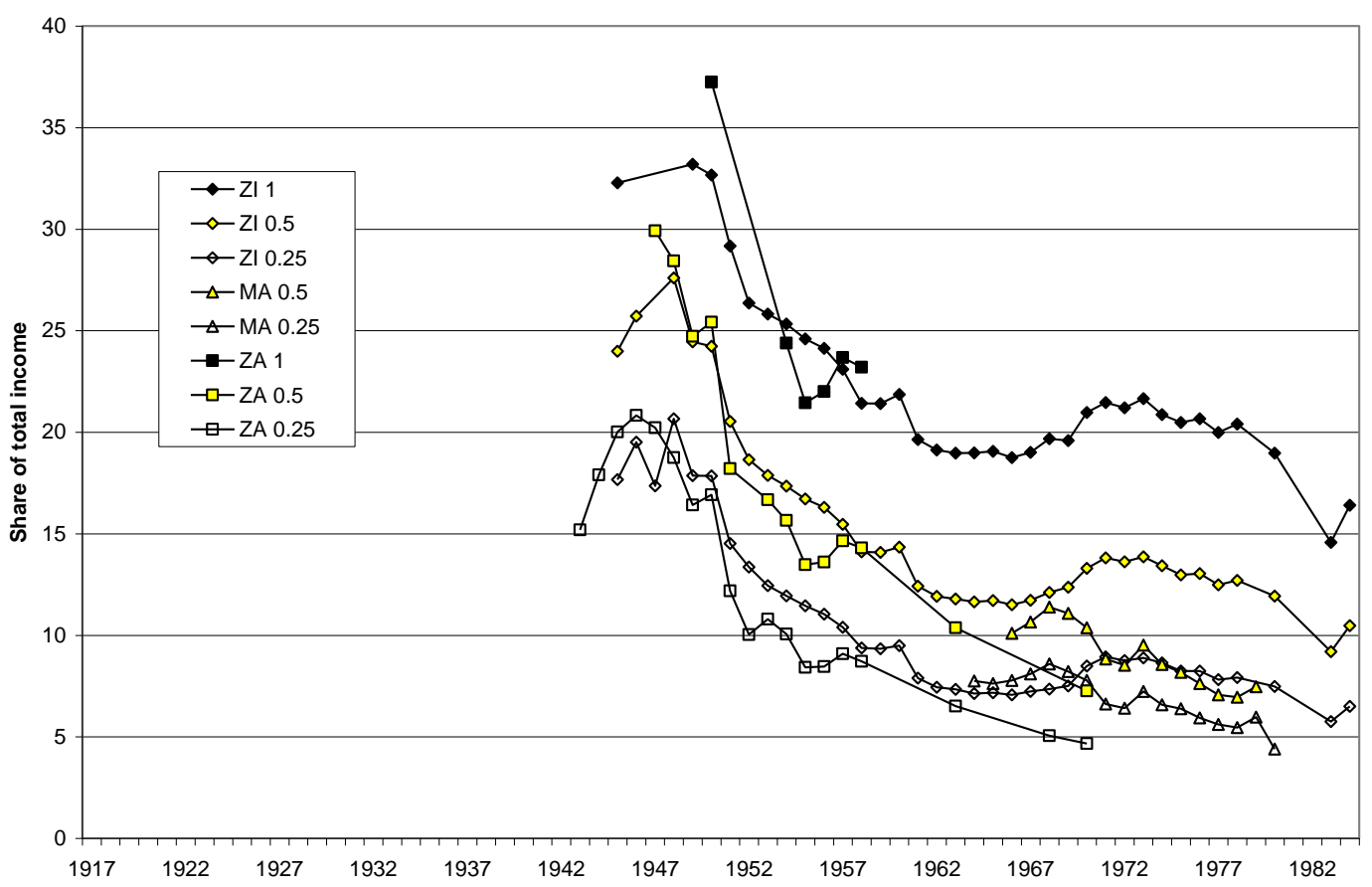

Figure 14 Comparison of supertax (dashed lines) and income tax (solid lines) results

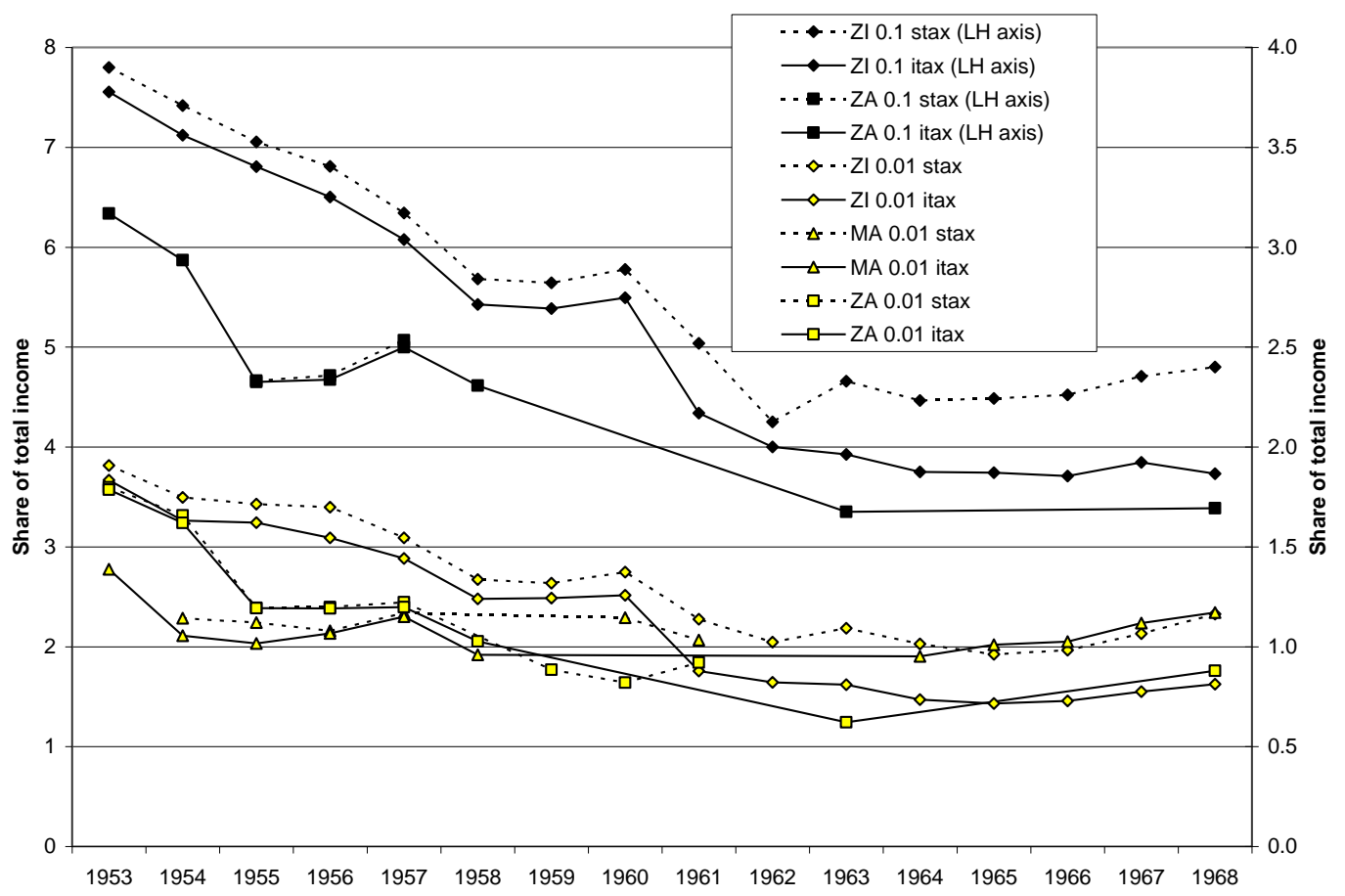


Table 5A Shares in total income in Malawi

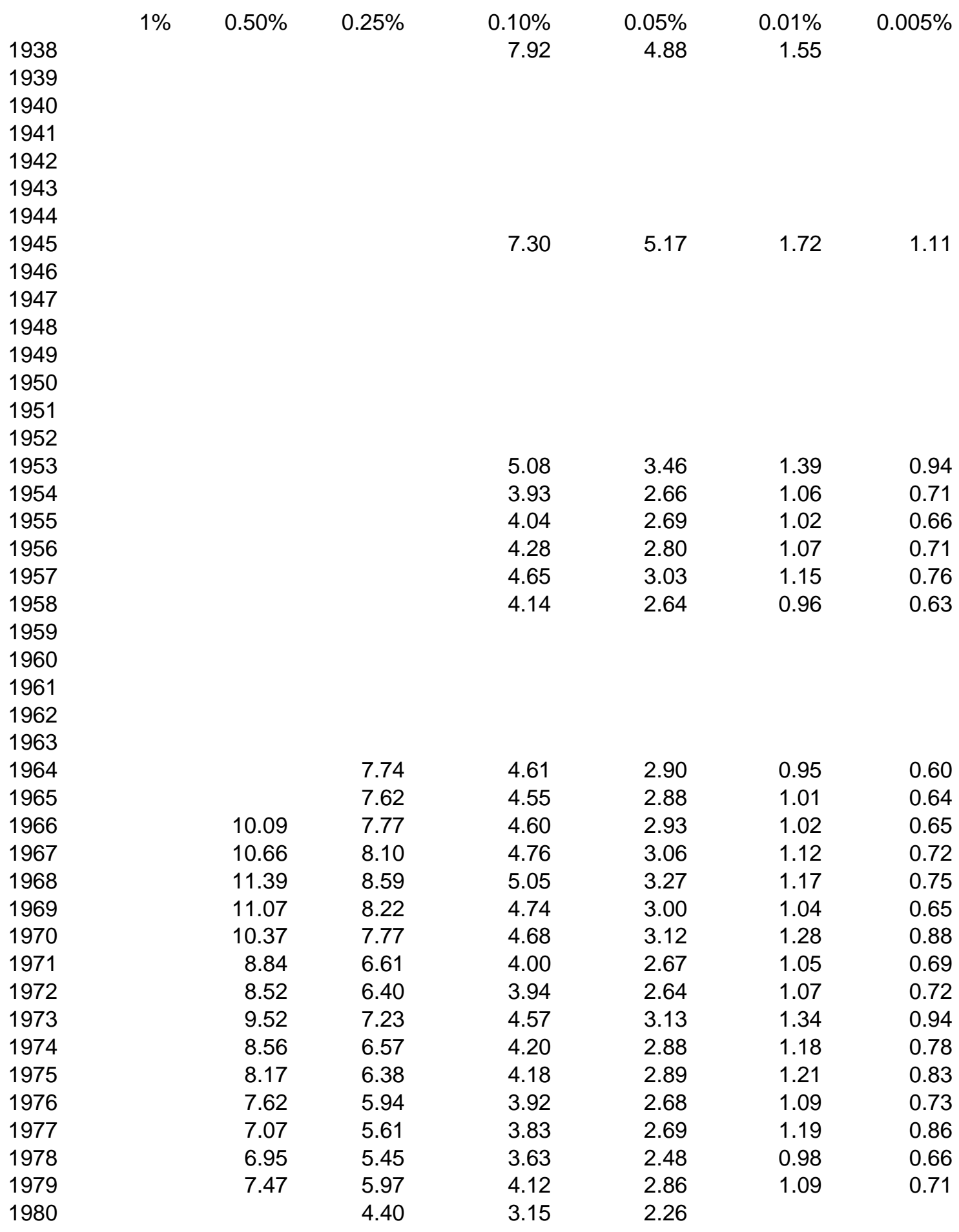


Table 5B Shares in total income in Zambia

\begin{tabular}{|c|c|c|c|c|c|c|c|}
\hline & $1 \%$ & $0.50 \%$ & $0.25 \%$ & $0.10 \%$ & $0.05 \%$ & $0.01 \%$ & $0.005 \%$ \\
\hline 1929 & & & & & & 4.67 & 3.19 \\
\hline 1930 & & & & & & 5.69 & 3.78 \\
\hline 1931 & & & & & & 4.98 & 3.39 \\
\hline 1932 & & & & & & 3.31 & 2.36 \\
\hline 1933 & & & & & & 2.42 & 1.60 \\
\hline 1934 & & & & & & 2.24 & 1.47 \\
\hline 1935 & & & & & & 2.13 & 1.43 \\
\hline 1936 & & & & & & 2.05 & 1.27 \\
\hline 1937 & & & & & & 1.52 & 1.02 \\
\hline 1938 & & & & & & & \\
\hline 1939 & & & & & & & \\
\hline 1940 & & & & & & & \\
\hline 1941 & & & & & & & \\
\hline 1942 & & & & & & & \\
\hline 1943 & & & 15.19 & 8.54 & 5.67 & 2.24 & \\
\hline 1944 & & & 17.90 & 10.24 & 6.92 & 2.65 & \\
\hline 1945 & & & 20.02 & 11.45 & 7.65 & 2.97 & \\
\hline 1946 & & & 20.83 & 12.31 & 8.41 & & \\
\hline 1947 & & 29.92 & 20.22 & 12.00 & 8.28 & & \\
\hline 1948 & & 28.44 & 18.76 & 11.07 & 7.66 & & \\
\hline 1949 & & 24.71 & 16.41 & 9.81 & 6.86 & & \\
\hline 1950 & 37.24 & 25.41 & 16.92 & 10.22 & 7.21 & & \\
\hline 1951 & & 18.21 & 12.19 & 7.28 & 5.11 & & \\
\hline 1952 & & & 10.03 & 5.98 & 4.21 & & \\
\hline 1953 & & 16.68 & 10.80 & 6.34 & 4.39 & 1.79 & 1.18 \\
\hline 1954 & 24.39 & 15.66 & 10.06 & 5.87 & 4.03 & 1.62 & 1.08 \\
\hline 1955 & 21.44 & 13.47 & 8.42 & 4.65 & 3.05 & 1.19 & 0.80 \\
\hline 1956 & 22.00 & 13.61 & 8.46 & 4.67 & 3.05 & 1.19 & 0.81 \\
\hline 1957 & 23.68 & 14.65 & 9.10 & 5.00 & 3.27 & 1.20 & 0.78 \\
\hline 1958 & 23.20 & 14.30 & 8.71 & 4.61 & 2.92 & 1.03 & 0.65 \\
\hline 1959 & & & & & & & \\
\hline 1960 & & & & & & & \\
\hline 1961 & & & & & & & \\
\hline 1962 & & & & & & & \\
\hline 1963 & & 10.36 & 6.51 & 3.35 & 2.03 & 0.62 & 0.37 \\
\hline 1964 & & & & & & & \\
\hline 1965 & & & & & & & \\
\hline 1966 & & & & & & & \\
\hline 1967 & & & & & & & \\
\hline 1968 & & & 5.05 & 3.39 & 2.34 & 0.88 & 0.57 \\
\hline 1969 & & & & & & & \\
\hline 1970 & & 7.26 & 4.66 & 2.52 & 1.60 & & \\
\hline
\end{tabular}


Table 5C Shares in total income in Zimbabwe

\begin{tabular}{|c|c|c|c|c|c|c|c|}
\hline & $1 \%$ & $0.50 \%$ & $0.25 \%$ & $0.10 \%$ & $0.05 \%$ & $0.01 \%$ & $0.005 \%$ \\
\hline 1917 & & & & & & 1.61 & 1.10 \\
\hline 1918 & & & & & 5.93 & 3.04 & 2.30 \\
\hline 1919 & & & & & 6.06 & 2.86 & \\
\hline 1920 & & & & & 7.18 & 3.58 & \\
\hline 1921 & & & & & 5.23 & 2.36 & 1.70 \\
\hline 1922 & & & & & 4.51 & 1.91 & 1.35 \\
\hline 1923 & & & & & 4.86 & 2.09 & 1.49 \\
\hline 1924 & & & & & 6.29 & 2.84 & 2.08 \\
\hline 1925 & & & & & 6.65 & 2.83 & 2.02 \\
\hline 1926 & & & & & 6.64 & 2.89 & \\
\hline 1927 & & & & 9.50 & 6.78 & 2.96 & \\
\hline 1928 & & & & & 6.34 & 2.76 & \\
\hline 1929 & & & & & 6.13 & 2.69 & \\
\hline 1930 & & & & 8.32 & 5.72 & 2.35 & 1.61 \\
\hline 1931 & & & & 11.57 & 8.00 & 3.37 & \\
\hline 1932 & & & & 10.98 & 7.66 & 3.26 & 2.25 \\
\hline 1933 & & & & 10.52 & 7.36 & 3.06 & 2.14 \\
\hline 1934 & & & & 10.04 & 6.97 & 2.82 & 1.86 \\
\hline 1935 & & & & 9.74 & 6.78 & 2.74 & 1.85 \\
\hline 1936 & & & & 9.05 & 6.18 & 2.39 & 1.54 \\
\hline 1937 & & & & 9.07 & 6.27 & 2.47 & 1.62 \\
\hline 1938 & & & & 8.53 & 5.90 & 2.22 & 1.39 \\
\hline 1939 & & & & 8.57 & 5.90 & 2.22 & 1.41 \\
\hline 1940 & & & & & & & \\
\hline 1941 & & & & & & & \\
\hline 1942 & & & & & & & \\
\hline 1943 & & & & & & & \\
\hline 1944 & & & & & & & \\
\hline 1945 & 32.28 & 23.99 & 17.67 & 11.37 & 7.94 & 3.21 & \\
\hline 1946 & & 25.72 & 19.52 & 12.86 & 9.13 & & \\
\hline 1947 & & & 17.35 & 11.84 & 8.58 & 3.72 & 2.47 \\
\hline 1948 & & 27.60 & 20.66 & 13.47 & 9.43 & & \\
\hline 1949 & 33.19 & 24.45 & 17.86 & 11.29 & 7.79 & & \\
\hline 1950 & 32.66 & 24.23 & 17.85 & 11.34 & 7.74 & 2.96 & 1.90 \\
\hline 1951 & 29.17 & 20.53 & 14.52 & 8.90 & 5.98 & 2.17 & 1.38 \\
\hline 1952 & 26.36 & 18.64 & 13.36 & 8.36 & 5.65 & 2.07 & 1.31 \\
\hline 1953 & 25.81 & 17.87 & 12.45 & 7.55 & 5.03 & 1.83 & 1.16 \\
\hline 1954 & 25.33 & 17.35 & 11.94 & 7.12 & 4.68 & 1.63 & 1.01 \\
\hline 1955 & 24.59 & 16.71 & 11.45 & 6.81 & 4.49 & 1.62 & 1.04 \\
\hline 1956 & 24.13 & 16.30 & 11.04 & 6.50 & 4.27 & 1.55 & 0.97 \\
\hline 1957 & 23.10 & 15.47 & 10.40 & 6.08 & 3.99 & 1.44 & 0.92 \\
\hline 1958 & 21.42 & 14.10 & 9.37 & 5.43 & 3.54 & 1.24 & 0.78 \\
\hline 1959 & 21.40 & 14.09 & 9.34 & 5.39 & 3.50 & 1.24 & 0.79 \\
\hline 1960 & 21.86 & 14.34 & 9.49 & 5.49 & 3.56 & 1.26 & 0.80 \\
\hline 1961 & 19.63 & 12.42 & 7.90 & 4.34 & 2.73 & 0.88 & 0.53 \\
\hline 1962 & 19.12 & 11.91 & 7.44 & 4.00 & 2.50 & 0.82 & 0.51 \\
\hline 1963 & 18.97 & 11.78 & 7.33 & 3.93 & 2.45 & 0.81 & 0.50 \\
\hline 1964 & 18.98 & 11.64 & 7.14 & 3.75 & 2.31 & 0.73 & 0.44 \\
\hline 1965 & 19.06 & 11.71 & 7.17 & 3.74 & 2.29 & 0.72 & 0.43 \\
\hline
\end{tabular}




$\begin{array}{llllllll}1966 & 18.75 & 11.50 & 7.06 & 3.71 & 2.28 & 0.73 & 0.44 \\ 1967 & 19.01 & 11.72 & 7.24 & 3.84 & 2.39 & 0.77 & 0.47 \\ 1968 & 19.67 & 12.11 & 7.34 & 3.73 & 2.47 & 0.81 & 0.51 \\ 1969 & 19.58 & 12.36 & 7.50 & 4.08 & 2.64 & 0.91 & \\ 1970 & 20.96 & 13.30 & 8.48 & 4.73 & 3.04 & 1.10 & 0.72 \\ 1971 & 21.46 & 13.81 & 8.93 & 5.02 & 3.24 & 1.24 & 0.87 \\ 1972 & 21.20 & 13.62 & 8.75 & 4.82 & 3.03 & 1.03 & 0.65 \\ 1973 & 21.65 & 13.87 & 8.89 & 4.88 & 3.08 & 1.05 & 0.64 \\ 1974 & 20.87 & 13.42 & 8.64 & 4.75 & 3.02 & 1.01 & \\ 1975 & 20.48 & 12.98 & 8.24 & 4.46 & 2.81 & 0.94 & \\ 1976 & 20.66 & 13.04 & 8.25 & 4.46 & 2.81 & 0.95 & \\ 1977 & 19.98 & 12.48 & 7.81 & 4.20 & 2.64 & 0.90 & \\ 1978 & 20.40 & 12.70 & 7.92 & 4.28 & 2.70 & 0.93 & \\ 1979 & & & & & & & \\ 1980 & 18.97 & 11.93 & 7.48 & 4.12 & 2.64 & & \\ 1981 & & & & & & & \\ 1982 & & & & & & & \\ 1983 & 14.57 & 9.20 & 5.75 & 3.08 & 1.95 & & \\ 1984 & 16.40 & 10.47 & 6.49 & 3.43 & 2.10 & & \end{array}$




\section{Conclusions}

The published reports on the administration of the personal income tax in the former colonies of Central Africa provide evidence about taxpayers and the distribution of income. The evidence relates to a small group of the population, and has to be qualified in a number of respects, but it is hoped that the findings are sufficient to demonstrate the potential of the income tax data in illustrating the historical experience of the colonial period and the years immediately following independence. It is hoped too that the historical research will serve to stimulate the analysis of income tax data for more recent years.

From studying the evidence for Malawi (formerly Nyasaland), Zambia (formerly Northern Rhodesia) and Zimbabwe (formerly Southern Rhodesia), it is apparent that the income taxpayers were a diverse group, which differed across countries and over time. They were certainly not limited to European settlers or to government officials. In Malawi and Zambia, the colonial tax was only levied on non-Africans, but a substantial proportion of income taxpayers in the former country were Indians. In Zimbabwe, there were African taxpayers before independence. In terms of economic activity, in Zambia and Zimbabwe, the taxable gross incomes of employees of government were outnumbered by those of private companies. In Zambia, a quarter of gross income came from self-employment, farming or the ownership of property. In Zimbabwe, these categories accounted for at least a quarter of income subject to tax. Comparing the countries in the Federation period, we see noticeable differences. As may be expected, mining employment is higher in Zambia, and agricultural profit income is higher in Zimbabwe. A substantial contribution is made by profit income (Malawi) and investment income (Zimbabwe).

Within the top income group represented by the income taxpayers, the distribution exhibited a degree of concentration that was low by international standards and falling over the 1930s in the Rhodesias, and in the Federation period (1953 to 1963) in all three countries (subject to the qualification concerning dividend income). At the time of independence (or UDI), the degree of concentration was relatively low, corresponding to Pareto coefficients in excess of 3. In Malawi, concentration increased after independence; in Zimbabwe, it first increased and then fell, reaching a low level in the early 1980s. At the same time, more detailed examination of the shape of the distribution suggests a more nuanced picture. There could be distinct changes in the shape of the distribution over time, and distinct differences between countries. To this extent, the upper tail cannot be adequately described by a single parameter, and a richer representation is necessary. 
When we turn to the position of the elite group relative to the population as a whole, we have to look at their share of total income. This depends on the estimated income totals, which can only, given the limited national accounts information, be approximate in nature. The totals employed here, which build on the work of pioneering researchers in the 1940s and 1950 s, have to be regarded with caution, but provide a basis for estimating the top income shares.

The evidence suggests that top income shares in the British Central African colonies were high in the 1920s and 1930s, although less so as the very top of the distribution was approached, reflecting the lower degree of concentration. In the post-war and Federation period there was a marked fall in top shares in Zambia and Zimbabwe, and less evidently in Malawi. This still left the top shares, after independence, at the start of the 1980s, that were high by the international standards of the time. Since the 1980s, top shares have risen in many countries, and it would be very interesting to know how far such a rise has taken place in Central Africa. For this, more recent income tax data are necessary. 


\section{Appendix: Sources of distributional data}

Table A1 Income tax data in Zimbabwe

\begin{tabular}{|c|c|c|}
\hline Income & Source of data & Notes \\
\hline & $\begin{array}{l}\mathrm{RCT}=\text { Report of the Commissioner of Taxes } \\
\text { for the year ended }\end{array}$ & \\
\hline & Data for Southern Rhodesia & \\
\hline 1917 & RCT $31^{\text {st }}$ March 1920, Schedule C & Ranges used from $£ 2,001$ upwards \\
\hline 1918 & RCT 31 $1^{\text {st }}$ March 1921, Schedule B & Ranges used from $£ 1,501$ upwards \\
\hline 1919 & RCT $31^{\text {st }}$ March 1922, Schedule B & Ditto \\
\hline 1920 & RCT $31^{\text {st }}$ March 1923, Schedule B & Ditto \\
\hline 1921 & RCT $31^{\text {st }}$ March 1924 , Schedule D & Ditto \\
\hline 1922 & RCT 31 $1^{\text {st }}$ March 1925, Schedule D & Ditto \\
\hline 1923 & RCT 31 $1^{\text {st }}$ March 1926, Schedule C & Ditto \\
\hline 1924 & RCT 31 $1^{\text {st }}$ March 1927, Schedule D & Ditto \\
\hline 1925 & RCT 31 $1^{\text {st }}$ March 1928, Schedule D & Ditto \\
\hline 1926 & RCT $31^{\text {st }}$ March 1929, Schedule D & Ditto \\
\hline 1927 & RCT $31^{\text {st }}$ March 1930, Schedule D & Ditto \\
\hline 1928 & RCT $31^{\text {st }}$ March 1931, Schedule D & Ditto \\
\hline 1929 & RCT 31 $1^{\text {st }}$ March 1932, Schedule D & Ditto \\
\hline 1930 & RCT 31 $1^{\text {st }}$ March 1933, Schedule D & Ranges used from $£ 1,001$ upwards \\
\hline 1931 & RCT 31 ${ }^{\text {st }}$ March 1934, Schedule D & Ditto \\
\hline 1932 & RCT 31 $1^{\text {st }}$ March 1935, Statement XI & Ditto \\
\hline 1933 & RCT 31 $1^{\text {st }}$ March 1936, Statement XI & Ditto \\
\hline 1934 & RCT 31 $1^{\text {st }}$ March 1936, Statement XII & Ditto; first-year assessment \\
\hline 1935 & RCT 31 $1^{\text {st }}$ March 1937, Statement XI & Ditto \\
\hline 1936 & RCT 31 $1^{\text {st }}$ March 1938, Statement XI & $\begin{array}{l}\text { Ditto; data in Shaul (1941, page } \\
\text { 383) }\end{array}$ \\
\hline 1937 & RCT 31 $1^{\text {st }}$ March 1939, Statement XI & $\begin{array}{l}\text { Ranges used from } £ 1,001 \text { upwards, } \\
\text { and first-year assessment }\end{array}$ \\
\hline 1938 & RCT 31 ${ }^{\text {st }}$ March 1940, Statement XI & Ditto \\
\hline 1939 & RCT 31 $1^{\text {st }}$ March 1941, Statement XI & Ditto \\
\hline 1945 & RCT 31 $1^{\text {st }}$ March 1947, Statement IX & $\begin{array}{l}\text { Ranges used from } \mathrm{f501;} \text { first year } \\
\text { assessment }\end{array}$ \\
\hline 1946 & RCT 31 $1^{\text {st }}$ March 1948, Statement IX & $\begin{array}{l}\text { Ranges used from } £ 801 \text {; first year } \\
\text { assessment }\end{array}$ \\
\hline 1947 & RCT 31 $1^{\text {st }}$ March 1949, Statement IX & Ditto \\
\hline 1948 & RCT $31^{\text {st }}$ March 1951,1952 and 1953 , page 25 & Ranges used from $£ 801$ \\
\hline 1949 & RCT $31^{\text {st }}$ March 1954, page 38 & Ditto \\
\hline 1950 & RCT $31^{\text {st }}$ March 1954 , page 40 & Ditto \\
\hline 1951 & RCT $31^{\text {st }}$ March 1954, page 42 & Ditto \\
\hline \multirow[t]{2}{*}{1952} & RCT $31^{\text {st }}$ March 1954, page 44 & Ditto; first year assessment \\
\hline & $\begin{array}{l}\text { Data published by the Federation of Rhodesia } \\
\text { and Nyasaland }\end{array}$ & \\
\hline 1953 & $\begin{array}{l}\text { Income Tax Statistics for the Income Years } \\
1953 / 54, \text { pages } 34 \text { and } 36\end{array}$ & Supertax data, pages 42 and 43 \\
\hline 1954 & $\begin{array}{l}\text { Income Tax Statistics for the Income Years } \\
1953 / 54 \text {, pages } 34 \text { and } 36\end{array}$ & Supertax data, pages 42 and 43 \\
\hline
\end{tabular}




\begin{tabular}{|c|c|c|}
\hline 1955 & $\begin{array}{l}\text { Income Tax Statistics for the Income Years } \\
\text { 1953/54, pages } 34 \text { and } 36\end{array}$ & Supertax data, pages 42 and 43 \\
\hline 1956 & $\begin{array}{l}\text { Income Tax Statistics for the Income Years } \\
1953 / 54 \text {, pages } 34 \text { and } 36\end{array}$ & Supertax data, pages 42 and 43 \\
\hline 1957 & $\begin{array}{l}\text { Income Tax Statistics for the Income Years } \\
\text { 1953/54, pages } 34 \text { and } 36\end{array}$ & Supertax data, pages 42 and 43 \\
\hline 1958 & $\begin{array}{l}\text { Income Tax Statistics for the Income Years } \\
1953 / 54 \text {, pages } 35 \text { and } 37\end{array}$ & Supertax data, pages 42 and 43 \\
\hline 1959 & $\begin{array}{l}\text { Income Tax Statistics for the Income Years } \\
1953 / 54 \text {, pages } 35 \text { and } 37\end{array}$ & Supertax data, pages 42 and 43 \\
\hline 1960 & $\begin{array}{l}\text { Income Tax Statistics for the Income Years } \\
1953 / 54 \text {, pages } 35 \text { and } 37\end{array}$ & Supertax data, pages 42 and 43 \\
\hline 1961 & $\begin{array}{l}\text { Income Tax Statistics for the Income Years } \\
1953 / 54-1962 / 63 \text {, pages } 35 \text { and } 37\end{array}$ & Supertax data, pages 42 and 43 \\
\hline \multirow[t]{2}{*}{1962} & $\begin{array}{l}\text { Income Tax Statistics for the Income Years } \\
1953 / 54-1962 / 63 \text {, pages } 35 \text { and } 37\end{array}$ & $\begin{array}{l}\text { Supertax data, pages } 42 \text { and } 43 \text {; } \\
\text { first year assessment }\end{array}$ \\
\hline & Data published for Rhodesia & \\
\hline 1963 & $\begin{array}{l}\text { First Report of the Commissioner of Taxes } \\
\text { for the period 1st January, } 1964 \text { to 30th } \\
\text { June, 1965, page } 19\end{array}$ & $\begin{array}{l}\text { Supertax data, page } 21 \text {; first year } \\
\text { assessment }\end{array}$ \\
\hline 1964 & $\begin{array}{l}\text { Second Report of the Commissioner of Taxes } \\
\text { for the year ended 30th June, 1966, page } 19\end{array}$ & Supertax data, page 21 \\
\hline 1965 & $\begin{array}{l}\text { Report of the Commissioner of Taxes for the } \\
\text { year ended 30th June, 1967, page } 20\end{array}$ & Supertax data, page 22 \\
\hline 1966 & $\begin{array}{l}\text { Report of the Commissioner of Taxes for the } \\
\text { year ended 30th June, 1968, page } 18\end{array}$ & Supertax data, page 20 \\
\hline 1967 & $\begin{array}{l}\text { Report of the Commissioner of Taxes for the } \\
\text { year ended 30th June, 1969, page } 17\end{array}$ & Supertax data, page 19 \\
\hline 1968 & $\begin{array}{l}\text { Report of the Commissioner of Taxes for the } \\
\text { year ended 30th June, 1970, page } 20\end{array}$ & Supertax data, page 22 \\
\hline 1969 & $\begin{array}{l}\text { Report of the Commissioner of Taxes for the } \\
\text { year ended 30th June, 1971, page } 17\end{array}$ & \\
\hline 1970 & $\begin{array}{l}\text { Report of the Commissioner of Taxes for the } \\
\text { year ended 30th June, 1972, page } 13\end{array}$ & \\
\hline 1971 & $\begin{array}{l}\text { Report of the Commissioner of Taxes for the } \\
\text { year ended 30th June, 1973, page } 15\end{array}$ & \\
\hline 1972 & Income Tax Statistics 1973-1974, page 15 & \\
\hline 1973 & Income Tax Statistics 1974-1975, page 15 & \\
\hline 1974 & Income Tax Statistics $1975-1976$, page 15 & \\
\hline 1975 & Income Tax Statistics 1976-1977, page 15 & \\
\hline 1976 & Income Tax Statistics 1977-1978, page 15 & \\
\hline 1977 & Income Tax Statistics 1978-1979, page 16 & \\
\hline 1978 & $\begin{array}{l}\text { Report of the Commissioner of Taxes for the } \\
\text { year ended 30th June, } 1980 \text {, page } 14\end{array}$ & \\
\hline 1980 & Income Tax Statistics 1981-1982, page 20 & \\
\hline 1983 & Income Tax Statistics 1983-1984, page 20 & \\
\hline 1984 & Income Tax Statistics 1984-1985, page 20 & \\
\hline
\end{tabular}


Table A2 Income tax data in Malawi

\begin{tabular}{|c|c|c|}
\hline $\begin{array}{l}\text { Income } \\
\text { vear }\end{array}$ & Source of data & Notes \\
\hline & $\begin{array}{l}\text { Fedn ITS = Income Tax Statistics for the } \\
\text { years } 1953 / 54 \text { to } 1958 / 59, \text { vol IV } \\
\text { AR = Annual Report of the Commissioner } \\
\text { of Taxes of Dept of Taxes, Ministry of } \\
\text { Finance, Malawi Government }\end{array}$ & \\
\hline 1938 & Deane 1948, pp $69-70$ & Classified by "Europeans" and "Asians" \\
\hline 1945 & Deane, 1953, p 79 and p 308 & Ditto \\
\hline 1953 & Fedn ITS, pp 26-27 & Supertax data, pp 30-31 \\
\hline 1954 & Fedn ITS, pp 26-27 & Supertax data, pp 30-31 \\
\hline 1955 & Fedn ITS, pp 26-27 & Supertax data, pp 30-31 \\
\hline 1956 & Fedn ITS, pp 26-27 & Supertax data, pp 30-31 \\
\hline 1957 & Fedn ITS, pp 26-27 & Supertax data, pp 30-31 \\
\hline 1958 & Fedn ITS, pp 26-27 & Supertax data, pp 30-31 \\
\hline 1959 & $\begin{array}{l}\text { (Fedtn) Seventh Report of the } \\
\text { Commissioner of Taxes for the year } \\
\text { ended } 30 \text { June 1961, App VIII and IX } \\
\text { (Supertax data only) }\end{array}$ & \\
\hline 1960 & $\begin{array}{l}\text { (Fedtn) Eighth Report of the } \\
\text { Commissioner of Taxes for the year } \\
\text { ended } 30 \text { June 1962, App VIII and IX } \\
\text { (Supertax data only) }\end{array}$ & \\
\hline 1961 & $\begin{array}{l}\text { (Fedtn) Ninth Report of the Commissioner } \\
\text { of Taxes for the year ended } 30 \text { June } \\
\text { 1963, App VIII and IX (Supertax data only) }\end{array}$ & \\
\hline \multicolumn{3}{|c|}{ 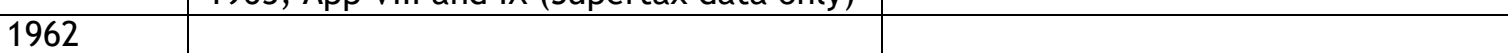 } \\
\hline 1963 & $\begin{array}{l}\text { No data on grounds of introduction of } \\
\text { PAYE }\end{array}$ & \\
\hline 1964 & $\begin{array}{l}\text { AR for the period } 1 \text { January } 1964 \text { to } 31 \\
\text { March } 1968, \text { pp } 42 \text { and } 46\end{array}$ & $\begin{array}{l}\text { same data in Public Sector Financial } \\
\text { Statistics } 1970, \text { table C3 }\end{array}$ \\
\hline 1965 & $\begin{array}{l}\text { AR for the period } 1 \text { January } 1964 \text { to } 31 \\
\text { March } 1968, \text { pp } 43 \text { and } 47\end{array}$ & Ditto \\
\hline 1966 & $\begin{array}{l}\text { AR for the period } 1 \text { January } 1964 \text { to } 31 \\
\text { March } 1968, \text { pp } 44 \text { and } 48\end{array}$ & Ditto \\
\hline 1967 & $\begin{array}{l}\text { AR for the period ended } 31 \text { March 1969, } \\
\text { pp } 19 \text { and } 20\end{array}$ & Ditto \\
\hline 1968 & $\begin{array}{l}\text { AR for the period ended } 31 \text { March 1970, } \\
\text { pp } 22 \text { and } 23\end{array}$ & \\
\hline 1969 & $\begin{array}{l}\text { AR for the period ended } 31 \text { March } 1971 \text {, } \\
\text { App } 8 \text { and } 9\end{array}$ & \\
\hline 1970 & $\begin{array}{l}\text { AR for the period ended } 31 \text { March 1972, } \\
\text { Tables } 6 \text { and } 8\end{array}$ & \\
\hline 1971 & $\begin{array}{l}\text { AR for the period ended } 31 \text { March 1973, } \\
\text { page } 25\end{array}$ & \\
\hline 1972 & $\begin{array}{l}\text { AR for the period ended } 31 \text { March } 1974 \text {, } \\
\text { page } 29\end{array}$ & \\
\hline 1973 & $\begin{array}{l}\text { AR for the period ended } 31 \text { March 1975, } \\
\text { Tables } 6 \text { and } 8\end{array}$ & \\
\hline 1974 & $\begin{array}{l}\text { AR for the period ended } 31 \text { March 1976, } \\
\text { Tables } 6 \text { and } 8\end{array}$ & \\
\hline
\end{tabular}




\begin{tabular}{|l|l|l|}
\hline 1975 & $\begin{array}{l}\text { AR for the period ended 31 March 1977, } \\
\text { Tables 6 and 8 }\end{array}$ & \\
\hline 1976 & $\begin{array}{l}\text { AR for the period ended 31 March 1978, } \\
\text { Tables 6 and 8 }\end{array}$ & \\
\hline 1977 & $\begin{array}{l}\text { AR for the period ended 31 March 1979, } \\
\text { Tables 6 and 8 }\end{array}$ & \\
\hline 1978 & $\begin{array}{l}\text { AR for the period ended 31 March 1980, } \\
\text { Tables 6 and 8 }\end{array}$ & \\
\hline 1979 & $\begin{array}{l}\text { AR for the period ended 31 March 1981, } \\
\text { Tables 6 and 8 }\end{array}$ & \\
\hline 1980 & \begin{tabular}{l} 
Statistical Yearbook1983, page 167 \\
\hline
\end{tabular}
\end{tabular}


Table A3 Income tax data in Zambia

\begin{tabular}{|c|c|}
\hline Income Year & $\begin{array}{l}\text { Fedn ITS = Income Tax Statistics for the years } 1953 / 54 \text { to } 1958 / 59 \text {, vol III, pub by } \\
\text { Fedtn }\end{array}$ \\
\hline 1929 & $\begin{array}{l}\text { (Northern Rhodesia) Income Tax Department Annual Report for the Year ended 31st } \\
\text { March 1932, Schedule B }\end{array}$ \\
\hline 1930 & $\begin{array}{l}\text { Income Tax Department Annual Report for the Year ended 31st March 1932, } \\
\text { Schedule B }\end{array}$ \\
\hline 1931 & $\begin{array}{l}\text { Income Tax Department Annual Report for the Year ended 31st March 1933, } \\
\text { Schedule B }\end{array}$ \\
\hline 1932 & $\begin{array}{l}\text { Income Tax Department Annual Report for the Year ended 31st December 1934, } \\
\text { Schedule B }\end{array}$ \\
\hline 1933 & $\begin{array}{l}\text { Income Tax Department Annual Report for the Year ended 31st December 1935, } \\
\text { Schedule B }\end{array}$ \\
\hline 1934 & $\begin{array}{l}\text { Income Tax Department Annual Report for the Year ended 31st December 1936, } \\
\text { Schedule B }\end{array}$ \\
\hline 1935 & $\begin{array}{l}\text { Income Tax Department Annual Report for the Year ended 31st December 1937, } \\
\text { Schedule B }\end{array}$ \\
\hline 1936 & $\begin{array}{l}\text { Income Tax Department Annual Report for the Year ended 31st December 1938, } \\
\text { Schedule B }\end{array}$ \\
\hline 1937 & $\begin{array}{l}\text { Income Tax Department Annual Report for the Year ended 31st December 1938, } \\
\text { Schedule B }\end{array}$ \\
\hline 1938 & \\
\hline 1939 & \\
\hline 1940 & \\
\hline 1941 & \\
\hline 1942 & \\
\hline 1943 & $\begin{array}{l}\text { Income Tax Department Annual Report for the Years 1945, } 1946 \text { and 1947, pages } \\
10 \text { and } 13\end{array}$ \\
\hline 1944 & $\begin{array}{l}\text { Income Tax Department Annual Report for the Years 1945, } 1946 \text { and 1947, pages } \\
11 \text { and } 14\end{array}$ \\
\hline 1945 & $\begin{array}{l}\text { Income Tax Department Annual Report for the Years 1945, } 1946 \text { and 1947, pages } \\
12 \text { and } 15\end{array}$ \\
\hline 1946 & Income Tax Department Annual Report for the Year 1948, pages 6 and 7 \\
\hline 1947 & Income Tax Department Annual Report for the Year 1949, pages 8 and 9 \\
\hline 1948 & Income Tax Department Report for the Year ended 31st March 1951, pages 8 and 9 \\
\hline 1949 & Income Tax Department Report for the Year ended 31st March 1952, pages 8 and 9 \\
\hline 1950 & $\begin{array}{l}\text { Income Tax Department Report for the Year ended 31st March 1953, pages } 10 \text { and } \\
11\end{array}$ \\
\hline 1951 & $\begin{array}{l}\text { Income Tax Department Report for the Year ended 31st March 1954, pages } 9 \text { and } \\
10\end{array}$ \\
\hline 1952 & $\begin{array}{l}\text { Income Tax Department Report for the Year ended 31st March 1954, pages } 9 \text { and } \\
10\end{array}$ \\
\hline 1953 & Fedn ITS, pages 31 and 32 \\
\hline 1954 & Fedn ITS, pages 31 and 32 \\
\hline 1955 & Fedn ITS, pages 31 and 32 \\
\hline 1956 & Fedn ITS, pages 31 and 32 \\
\hline 1957 & Fedn ITS, pages 31 and 32 \\
\hline 1958 & Fedn ITS, pages 31 and 32 \\
\hline
\end{tabular}




\begin{tabular}{|c|c|}
\hline 1959 & Seventh Report of the Commissioner of Taxes for the year ended 30 June 1961 \\
\hline 1960 & Eighth Report of the Commissioner of Taxes for the year ended 30 June 1962 \\
\hline 1961 & Ninth Report of the Commissioner of Taxes for the year ended 30 June 1963 \\
\hline 1962 & Tenth Report of the Commissioner of Taxes for the year ended 30 June 1964 \\
\hline 1963 & $\begin{array}{l}\text { AR for the period } 1 \text { Jan } 1964 \text { to 30th June 1965, pub by Dept of Taxes, Ministry of } \\
\text { Finance, Republic of Zambia (first annual report) }\end{array}$ \\
\hline 1964 & $\begin{array}{l}\text { AR for the period } 1 \text { July } 1965 \text { to 30th June 1966, pub by Dept of Taxes, Ministry of } \\
\text { Finance, Republic of Zambia }\end{array}$ \\
\hline 1965 & $\begin{array}{l}\text { Report of the commissioner for Taxes for the period } 1 \text { July } 1966 \text { to } 31 \text { st Dec } 1967 \text {, } \\
\text { pub by Ministry of Finance }\end{array}$ \\
\hline 1966 & $\begin{array}{l}\text { AR for the period } 1 \text { Jan } 1968 \text { to } 31 \text { st Dec } 1968 \text {, pub by Office of the Vice President, } \\
\text { Finance Division }\end{array}$ \\
\hline 1967 & \\
\hline 1968 & $\begin{array}{l}\text { Report of the Commissioner of Taxes for the period } 1 \text { January } 1968 \text { to 31st Dec } \\
\text { 1968, pub Office of the Vice-President, Finance Division }\end{array}$ \\
\hline 1969 & $\begin{array}{l}\text { Report of the Commissioner of Taxes for the year ended 31st March 1971, pub Min } \\
\text { of Planning and Finance }\end{array}$ \\
\hline 1970 & $\begin{array}{l}\text { Report of the Commissioner of Taxes for the year 1st April } 1971 \text { to 31st March 1972, } \\
\text { pub Min of Planning and Finance }\end{array}$ \\
\hline 1971 & $\begin{array}{l}\text { Report of the Commissioner of Taxes for the year 1st April } 1972 \text { to 31st March 1973, } \\
\text { pub Min of Planning and Finance }\end{array}$ \\
\hline 1972 & Report of the Commissioner of Taxes for the year 1st April 1973 to 31st March 1974 \\
\hline 1973 & \\
\hline 1974 & Report of the Commissioner of Taxes for the year 1st April 1975 to 31st March 1976 \\
\hline 1975 & Report of the Commissioner of Taxes for the year 1st April 1976 to 31st March 1977 \\
\hline 1976 & Report of the Commissioner of Taxes for the year 1st April 1977 to 31st March 1978 \\
\hline 1977 & Report of the Commissioner of Taxes for the year 1st April 1978 to 31st March 1979 \\
\hline 1978 & Report of the Commissioner of Taxes for the year 1st April 1979 to 31st March 1980 \\
\hline
\end{tabular}




\section{Bibliography}

Alvaredo, F and Atkinson, A B, 2012, "Top incomes in South Africa over a century", unpublished.

Atkinson, A B, 2005, "Top incomes in the UK over the twentieth century", Journal of the Royal Statistical Society, vol 168: 325-343.

Atkinson, A B, 2014, "Top incomes in the New World and the shape of the distribution: A case study of Venezuela 1956", unpublished.

Atkinson, A B, Piketty, T and Saez, E, 2011, "Top incomes in the long run of history", Journal of Economic Literature, vol 49: 3-71.

Baker, C, 1975, "Tax collection in Malawi: an administrative history, 1891 1972", The International Journal of African Historical Studies, vol 8: 40-62.

Baldwin, R E, 1966, Economic development and export growth: A study of Northern Rhodesia, 1920-1960, University of California Press, Berkeley.

Borland, W C W, and Irvine, A G, 1954, The national income and social accounts of Northern Rhodesia, 1945-1953, Central African Statistical Office, Salisbury.

Clark, C, 1953, The conditions of economic progress, second edition, Macmillan, London.

Colonial Office, 1952-55, An economic survey of the colonial territories, three volumes, HMSO, London.

Colonial Office, 1954, Report of the second conference of Colonial Government Statisticians, 1953, Colonial No. 301, HMSO, London.

Deane, P, 1948, The measurement of colonial national incomes: An experiment, Cambridge University Press, Cambridge.

Deane, P, 1953, Colonial social accounting, Cambridge University Press, Cambridge.

Frankel, S H (chair), 1945, Report of the Commission of Inquiry into the Mining Industry of Southern Rhodesia, Controller of Printing and Stationery, Salisbury.

Gastwirth, J L, 1972, "The estimation of the Lorenz curve and Gini index", Review of Economics and Statistics, vol 54: 306-316. 
Hailey, Lord, 1957, An African survey revised 1956, Oxford University Press, London.

Irvine, A G, 1950, The national income and social accounts of Northern Rhodesia, 1945-1949, Central African Statistical Office, Salisbury.

Irvine, A G, 1955, "A note on the national income and social accounts of Northern Rhodesia, 1945-1953", South African Journal of Economics, vol 23: 364-369.

Kuczynski, R R , 1949, Demographic survey of the British colonial empire, volume II, Cambridge University Press, London.

Kuznets, S, 1963, "Quantitative aspects of the economic growth of nations VIII: Distribution of income by size", Economic development and cultural change, vol XI: 1-80.

Maddison, A, 2003, The world economy: Historical statistics, OECD, Paris.

Mitchell, B R, 1982, International historical statistics: Africa and Asia, New York University Press, New York and London.

Murray, S S, 1932, A handbook of Nyasaland, Crown Agents. London.

Piketty, T, 2001, Les hauts revenus en France au 20ème siècle, Grasset, Paris

Shaul, J R H, 1941, "The Pareto Law and the distribution of incomes in Southern Rhodesia”, South African Journal of Science, vol 37: 373-383.

Shaul, J R H, 1960, "National accounts of the Federation of Rhodesia and Nyasaland", South African Journal of Economics, vol 28: 247-262. 